\title{
Phylogeography of Arabidopsis halleri (Brassicaceae) in mountain regions of Central Europe inferred from cpDNA variation and ecological niche modelling
}

Pawel Wasowicz, Maxime Pauwels, Andrzej Pasierbinski, Ewa M Przedpelska-Wasowicz, Alicja A. Babst-Kostecka, Pierre SaumitouLaprade, Adam Rostanski

The present study aimed to investigate phylogeographical patterns present within $A$. halleri in Central Europe. 1281 accessions sampled from 52 populations within the investigated area were used in the study of genetic variation based on chloroplast DNA. Over 500 high-quality species occurrence records were used in ecological niche modelling experiments. We evidenced the presence of a clear phylogeographic structure within $A$. halleri in Central Europe. Our results showed that two genetically different groups of populations are present in western and eastern part of the Carpathians. The hypothesis of the existence of a glacial refugium in the Western Carpathians adn the Bohemian Forest cannot be rejected from our data. It seems, however, that the evidence collected during the present study is not conclusive. The area of Sudetes was colonised after LGM probably by migrants from the Bohemian Forest. 
- Phylogeography of Arabidopsis halleri

\title{
(Brassicaceae) in mountain regions of Central Europe inferred from cpDNA variation and ecological niche modelling
}

\author{
Pawel Wasowicz ${ }^{1}$, Maxime Pauwels ${ }^{2}$, Andrzej Pasierbinski ${ }^{3}$, Ewa Maria \\ Przedpelska-Wasowicz ${ }^{4}$, Alicja Babst-Kostecka ${ }^{5}$, Pierre \\ Saumitou-Laprade ${ }^{6}$, and Adam Rostanski ${ }^{7}$ \\ ${ }^{1}$ Icelandic Institute of Natural History, Borgir vid Nordurslod, P.O. Box 180, 602 Akureyri, \\ Iceland, pawasowicz@gmail.com, pawel@ni.is \\ ${ }^{2}$ Unité Evo-Eco-Paléo (EEP) - UMR 8198, Université de Lille - Sciences et Technologies, \\ CNRS, Villeneuve d'Ascq 59655,France \\ ${ }^{3}$ Department of Botany and Nature Protection, Faculty of Biology and Environmental \\ Protection, University of Silesia, Katowice, Poland \\ ${ }^{4}$ Institute of Botany, University of Warsaw, Warszawa, Poland \\ ${ }^{5}$ Department of Ecology, Institute of Botany, Polish Academy of Sciences, Kraków, \\ Poland \\ ${ }^{6}$ Unité Evo-Eco-Paléo (EEP) - UMR 8198, Université de Lille - Sciences et Technologies, \\ CNRS, Villeneuve d'Ascq 59655,France \\ ${ }^{7}$ Department of Botany and Nature Protection, Faculty of Biology and Environmental \\ Protection, University of Silesia, Katowice, Poland
}

\section{ABSTRACT}

The present study aimed to investigate phylogeographical patterns present within $A$. halleri in Central Europe, to propose hypotheses explaining the emergence of these patterns and to formulate hypotheses on the formation of the present-day range of $A$. halleri in the region. 1281 accessions sampled from 52 populations within the investigated area were used in the study of genetic variation based on chloroplast DNA. Over 500 high-quality species occurrence records were used in ecological niche modelling experiments. We evidenced the presence of a clear phylogeographic structure within $A$. halleri in Central Europe. Our results showed that two genetically different groups of populations are present in western and eastern part of the Carpathians. The hypothesis of the existence of a glacial refugium in the Western Carpathians and the Bohemian Forest cannot be rejected from our data. It seems, however, that the evidence collected during the present study is not conclusive. The area of Sudetes was colonised after LGM probably by migrants from the Bohemian Forest.

Keywords: Arabidopsis halleri, phylogeography, Carpathians, Alps, Sudetes, Harz, Quaternary, taxonomy

\section{INTRODUCTION}

A phylogeographical approach has been used in numerous studies addressing the Quaternary history of the flora of Europe, shaped by repeated range contractions during cold 
periods and subsequent extension of available habitats during warmer periods (Hewitt, 2000, 2004). These range oscillations, altering the patterns of gene flow, have been found to contribute to the genetic differentiation that can be detected between contemporary populations (Médail and Diadema, 2009). The presence of this differentiation has allowed (with the advent of phylogeography) insights into processes responsible for range formation, reconstruction of (re)colonisation routes, detection of refugial areas and unravelling historical relationships among different parts of the contemporary species distribution.

Areas of relative ecological stability that provided suitable habitats for species survival during periods of glaciation are termed refugia (Tribsch and Schönswetter, 2003). Numerous studies carried out so far showed that major glacial refugia were located in the southern part of Europe (Taberlet et al., 1998; Hewitt, 1999). Recently, the possibility of full-glacial survival of temperate species at northern latitudes in so-called northern or cryptic refugia (Stewart and Lister, 2001) was hypothesised and subsequently supported by fossil records from several species (Willis and Van Andel, 2004). There is, however, still little molecular evidence for the existence of "northern refugia" in Central Europe (Daneck et al., 2011).

In Europe the potential for phylogeographical research has been exploited intensively in the Alps, where the abundance and complexity of the available phylogeographic studies has already resulted in synthetic and comparative analyses (Schönswetter et al., 2005; Alvarez et al., 2009). The situation is quite different in other mountain ranges of Central Europe such as the Carpathians, Sudetes, Bohemian Forest (Sumava) and Harz Mts. A recent literature review pointed out clearly that the history of species range formation in the mountains of Central Europe is still only poorly known from phylogeographical studies (Ronikier, 2011).

Arabidopsis halleri with its pattern of occurrence covering nearly all mountain regions of Central Europe (Jalas and Suominen, 1994) seems to be an interesting model taxon to address all the problems raised above. Previous phylogeographical studies focused on the species, evidenced the presence of two major units within the species range and attributed the emergence of these units to vicariance associated with the isolation of two large populations groups during the Quaternary, which were located in Central and Southern Europe (Pauwels et al., 2012). The sampling density adopted in the study was, however, too low to address the question of A. halleri range formation in the mountains of Central Europe.

In the light of these considerations, we focused our study on the poorly investigated area covering the Carpathians, Sudetes, Bohemian Forest and Harz Mountains in order to reconstruct the phylogeographic history of this montane species Arabidopsis halleri. This approach allowed us to overcome another limitation originating from the fact that the vast majority of phylogeographical analyses carried out hitherto on mountain species in Europe has been focused on alpine and arctic-alpine species, while our knowledge of the phylogeographic patterns present within herbaceous species having the centre of its occurrence in lower vegetation belts (subalpine and montane) remains, with some notable exceptions (Despres et al., 2002; Stachurska-Swakoń et al., 2013), much poorer.

We aimed to answer the following questions:

1. Is there any geographically structured genetic variation in A.halleri within the 
investigated area?

2. Is there any evidence for the existence of glacial refugia in Central Europe?

3. What is the origin of A. halleri populations in the Carpathians and Sudetes?

\section{MATERIALS \& METHODS}

\section{The study species}

Arabidopsis halleri (L.) O' Kane \& Al-Shehbaz is a perennial, self-incompatible and highly outcrossing (Llaurens et al., 2008), stoloniferous herb with a highly disjunctive distribution between Europe and the Far East. It occurs in mountain and upland environments on slopes, forest margins, rocky crevices and river banks from 200 to $2200 \mathrm{~m}$ a.s.l. In Europe, it is widely distributed in the Alps, Carpathians, Sudetes and Dinaric Alps (Jalas and Suominen, 1994). Its distribution also covers some upland regions north from the Alps (including the Harz Mountains) and the Western Carpathians (Jalas and Suominen, 1994). The species is highly variable in leaf morphology, flower colour and traits connected with the development of stolons. At least three subspecies are quite distinct in terms of morphological variation (Al-Shehbaz and O'Kane, 2002): A. halleri subsp. halleri and A. halleri subsp. ovirensis occur in Europe, whereas A. halleri subsp. gemmifera occurs in the Far East. According to other authors (Kolník and Marhold, 2006) the species can be alternatively divided into five distinct morphological subspecies, with four occurring in Europe. Only diploid $(2 n=2 X=16)$ individuals have so far been reported from throughout the distribution range (Al-Shehbaz and O'Kane, 2002; Kolník and Marhold, 2006). Other species from the genus Arabidopsis also co-occur within the investigated area (A.thaliana, A.arenosa, A.neglecta, A. lyrata). A recent study has shown that reticulation and hybridization among lineages that might have transferred cpDNA types from one lineage into the other is unlikely (Koch and Matschinger, 2007). The same authors have pointed out that cpDNA type diversity may predate separation of the main evolutionary lineages within the genus (Koch and Matschinger, 2007).

\section{Sampling and DNA extraction}

We sampled 1281 individuals from 52 populations (Table 1) scattered across the species range in seven geographic regions of Central and Eastern Europe (see Supplemental Information 1). Twenty-five populations included in the present study have been already described in previous studies (Pauwels et al., 2005, 2012). In the present study, sampling was extended to improve sampling representativeness in the area of the Sudetes as well as the Carpathians. All the locations sampled belonged to the native species range (Jalas and Suominen, 1994). In each locality, individual samples were taken from plants separated by at least three metres to avoid sampling clones (Van Rossum et al., 2004). Sample size generally reflected population size and was almost exhaustive in small populations. Permits for plant sampling were obtained from the following national parks: Krkonossky narodni park (CZ, permit no. 01004/2009), Karkonoski Park Narodowy (PL permits no. 24/2007, 2/2008)/, Tatrzanski Park Narodowy (PL, permit no. NB-056/119/07), Bieszczadzki Park Narodowy (PL, permits no. 54/06, 40/07) and Karpatskij biosfernij Zapovidnik (UA, permit no. 01110607/07 ). In other cases sampling was done outside protected areas. 
Collected leaf tissue was immediately dried in silica gel prior to molecular analysis. DNA was extracted from 10 to $15 \mathrm{mg}$ of dry material using NucleoSpin $® 96$ Plant (Macherey-Nagel), and PCR amplifications were performed on 1:20 dilutions.

\section{Genetic analysis Genotyping procedure}

During the genotyping process we screened 12 polymorphic sites previously detected by PCR-RFLP in three cpDNA regions: $t r n \mathrm{~K}$ intron and two intergenic regions $(t r n \mathrm{C}-$ $t r n \mathrm{D}, p s b \mathrm{C}-\mathrm{trnS}$ ). The observed polymorphisms are briefly characterized in Table 2 . In contrast to Pauwels et al. (2005), however, three different genotyping methods were employed.

\section{SNaPshot assay}

After PCR amplification of the three cpDNA regions of interest, we used SNaPshot assay for simultaneous detection of seven single nucleotide polymorphisms (SNP, cf. Table 2). In the analysis we employed ABI Prism $\AA$ SNaPshot $\AA$ Multiplex Kit (Applied Biosystems) and followed the protocol given by the manufacturer.

The following PCR conditions were utilized: a total volume of $15 \mu \mathrm{l}$ consisting of $3 \mu 1$ of template DNA (20-100 ng), $6.225 \mu 1$ of water, $1.5 \mu 1$ of 10X PCR Buffer, $2.1 \mu \mathrm{l}$ of $25 \mathrm{mM}$ solution of $\mathrm{MgCl}_{2}, 1.2 \mu \mathrm{l}$ of $2.5 \mathrm{mM}$ solution of dNTP, $0.3 \mu \mathrm{l}$ of BSA solution $(10 \mathrm{mg} / \mathrm{ml}), 0.3 \mu \mathrm{l}$ of $10 \mathrm{mM}$ solution of each primer and $0.075 \mu \mathrm{l}$ of AmpliTaq $\AA$ DNA Polymerase $(5 \mathrm{U} / \mu \mathrm{l})$. The reaction was carried out in Mastercycler $\AA$ ep gradient $\mathrm{S}$ thermal cycler using one cycle of $5 \mathrm{~min}$ at $95^{\circ} \mathrm{C}$, and 36 cycles of 45 s at $92^{\circ} \mathrm{C}, 45 \mathrm{~s}$ at $58^{\circ} \mathrm{C}-62^{\circ} \mathrm{C}$ (depending of the primers sequences, precise protocol upon request); and $2 \mathrm{~min} 30 \mathrm{~s}$ at $72^{\circ} \mathrm{C}$, followed by one cycle of $10 \mathrm{~min}$ at $72^{\circ} \mathrm{C}$. The primer sequences for specific PCR amplifications are given in Supplemental Information 2. Amplicons were used for genotyping following the manufacturer's instruction (ABI

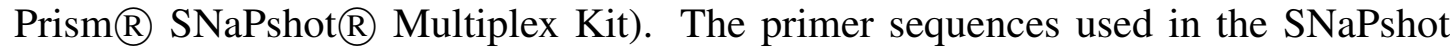
reaction are given in Supplemental Information 3. Sample electrophoresis was carried out in an ABI PRISM $\AA 3130 x 1$ Genetic Analyzer (Applied Biosystems) using a capillary of $36 \mathrm{~cm}$, POP 4 Migration Buffer and Dye Set E5. The data were collected using Foundation Data Collection 4.0 software and analyzed with GeneMapper 4.0.

\section{CAPS assay}

The CAPS assay was used for genotyping three SNP polymorphisms in the $\operatorname{trn} \mathrm{C}-\operatorname{trn} \mathrm{D}$ region by specifically amplifying the genomic region containing the SNP polymorphisms mentioned in Table 2 and digesting the amplification product using the AcsI restriction enzyme. The PCR primer sequences were given in Supplemental Information 3. The PCR mixture and the conditions followed the protocol given above for SNaPshot assay. Restriction enzyme reaction was performed on a total volume of $20 \mu \mathrm{l}$ consisting of 10 $\mu 1$ of PCR product and $10 \mu 1$ of restriction mixture containing $5.9 \mu 1$ of water, $2 \mu 1$ of SuRe/Cut Buffer B 10X, $2 \mu 1$ of $2 \mathrm{mM}$ solution of spermidine and $0.1 \mu 1$ of AcsI solution $(10 \mathrm{U} / \mu 1)$. The mixture was then incubated at $50^{\circ} \mathrm{C}$ for 1 hour, followed by enzyme deactivation at $70^{\circ} \mathrm{C}$ for $15 \mathrm{~min}$. Both procedures were carried out in Mastercycler $\AA$ ep gradient $\mathrm{S}$ (Eppendorf) thermal cyclers. Fragments were separated by electrophoresis on $2 \%$ agarose gels stained by ethidium bromide and photographed with BioImage system (Bioprobe) under UV light. 


\section{PCR length difference assay}

Two indel polymorphisms in the $\operatorname{trn\mathrm {K}}$ and $\operatorname{trn} \mathrm{C}-\mathrm{trn \textrm {D }}$ regions (cf. Table 2) were genotyped from a PCR product length difference assay following the method described by Oetting et al. (Oetting et al., 1995). The PCR mixture followed the protocol given above for SNaPshot assay. The primer sequences used in this reaction are given in Supplemental Information 2. PCRs were carried out in Mastercycler $\AA$ ep gradient S (Eppendorf) thermal cyclers using one cycle of $5 \mathrm{~min}$ at $95^{\circ} \mathrm{C}$, and 36 cycles of $30 \mathrm{~s}$ at $94^{\circ} \mathrm{C}, 30 \mathrm{~s}$ at $51^{\circ} \mathrm{C}$ or $56^{\circ} \mathrm{C}$ (depending of the primers sequences); and $30 \mathrm{~s} \mathrm{at} 72^{\circ} \mathrm{C}$, followed by one cycle of $10 \mathrm{~min}$ at $72^{\circ} \mathrm{C}$. Fragments were separated on $8 \%$ polyacrylamide gels using a Li-Cor 4200 Global IR2 DNA Sequencer.

\section{Data analysis}

Since cpDNA is a non-recombining molecule, alleles observed at all twelve loci were combined into cpDNA haplotypes (chlorotypes, Table 3). Chlorotype nomenclature is fully consistent with our previous study (Pauwels et al., 2005).

\section{Phylogenetic relationships between chlorotypes}

A minimum spanning tree (MST) was constructed on the basis of a distance matrix reflecting molecular differences between each pair of chlorotypes using a modification of the algorithm described by Rohlf (Rohlf, 1973). Computations were made using the software Arlequin 3.11 (Excoffier et al., 2005). The MST algorithm assumes that each chlorotype is linked to all the other chlorotypes by one or a series of mutations and constructs a tree with minimal number of required mutational steps between haplotypes (Excoffier and Smouse, 1994). The position of a chlorotype in the MST also gives information regarding relative age, since older haplotypes are expected to locate in internal nodes of the tree (Posada and Crandall, 2001).

\section{Molecular diversity indices}

Allelic richness $\left(\mathrm{A}_{\mathrm{Sc}}\right)$ was calculated for each population according to the rarefaction method (El Mousadik and Petit, 1996; Kalinowski, 2004) using Fstat software (Goudet, 2013). Estimates of $A_{S c}$ were standardized to the smallest sample size $(n=7)$. Chlorotypic diversity $\left(\mathrm{H}_{\mathrm{Sd}}\right)$ and its sampling variance were calculated according to the methodology given by Nei (1987) for each population separately and over the whole sample using Arlequin 3.11 (Excoffier et al., 2005). To test for differences in allelic richness between the investigated geographical regions we employed a permutation test implemented in Fstat (Goudet, 2013) using 10000 permutations of populations between geographical regions.

\section{Population genetic structure}

To reveal structure in our dataset we used Spherikm (Hill et al., 2013), software designed to analyse multivariate datasets by means of spherical k-means clustering (SKMC). The computations were based on a matrix of chlorotype frequencies in analysed populations. The statistically optimal number of clusters was assessed using the quasi-Akaike information criterion (Hill et al., 2013). The partitioning of genetic variation within and between groups of populations identified by SKMC as well as between geographical regions was tested by analysis of molecular variance (AMOVA) using Arlequin 3.11 (Excoffier et al., 2005). AMOVA computations were based on a distance matrix among 
the identified chlorotypes. We also carried out separate AMOVA analysis for populations within each geographical region in order to asses the strength of the separation between the regions.

\section{Distribution modelling}

To reconstruct the potential distribution of $A$. halleri we used two palaeoclimate scenarios: mid Holocene (ca. 6 kyr BP) and Last Glacial Maximum (LGM, ca. $22 \mathrm{kyr}$ BP). Paleoclimatic data were obtained from simulations in the following Global Climate Models: CCSM4, MIROC-ESM and MPI-ESM-P. Bioclimatic variables calculated on the basis of these models and downscaled to 5 arc-minute resolution were downloaded from the WorldClim dataset (Hijmans et al., 2005)(http://www.worldclim.org), together with present-day climate data at the same resolution. We tested all the variables for multicollinearity by examining the cross-correlations among them (Pearson's r) based on the 544 species occurrence records. Highly correlated variables ( $r>0.7)$ were excluded from the models (Dormann et al., 2013), resulting in 8 variables representing temperature and precipitation: annual mean temperature (bio_1), mean diurnal temperature range (bio_2), isothermality (bio_3), temperature seasonality (bio_4), mean temperature of the wettest quarter (bio_8), mean temperature of the driest quarter (bio_9), annual precipitation (bio_12) and precipitation seasonality (bio_15). Areas covered by ice sheet (Ehlers et al., 2004) were excluded from the climatic layers of the LGM paleoclimate scenarios.

Distribution data were obtained from GBIF database (http://www.gbif.org/) as well as from our own field research carried out in France, Germany, Poland, Austria, Czech Republic, Slovakia and Ukraine. After initial screening for duplicates and data aggregation into a 5 minute resolution raster we obtained 544 unique records that were used to calibrate and validate the models (Supplemental Information 4). Data handling was done using GRASS GIS ver. 6.4 (http://grass.osgeo.org).

Seven different algorithms implemented in biomod2 ver. 3.1-48 (Thuiller et al., 2009; Thuiller, 2014) and MaxEnt ver. 3.3.3k (Phillips et al., 2006) were used : two regression methods (GLM - generalized linear models; GAM - generalized additive models), two classification methods (FDA - flexible discriminant analysis; CTA - classification tree analysis) and three machine-learning methods (GBM - generalized boosting model; RF - random forest for classification and regression and MAXENT - maximum entropy modeling). For each of the algorithms we ran 10 pseudo-absence replicates with 10000 of pseudo-absences, to meet the minimum requirements of the algorithms used (BarbetMassin et al., 2012). The models were fitted with 10 different random presence sets for each pseudo-absence run. This gave us a total of 100 replicates for each of the algorithms. Occurrence records were randomly divided into two subsets containing data for calibration (70\%) and evaluation (30\%) of models. We used the area under the receiver-operating characteristic (ROC) curve and true skill statistic (TSS) to evaluate model performance. These accuracy measures were calculated with reference to the current potential distribution only, due to the lack of independent and reliable fossil records for A. halleri.

Permutation procedure was used to define contributions of the variables to the models. In order to identify areas classified as suitable for species survival by the majority of algorithms (final consensus models) we performed ensemble forecasting (Thuiller et al., 2009). This procedure was used to eliminate the least reliable models (TSS $<0.7)$ 
and provided 7 ensemble models: mean of probabilities, coefficient of variation of probabilities, two models of confidence interval around the mean of probabilities, median of probabilities, models committee averaging (average of binary predictions) and weighted mean of probabilities. Binary transformation was carried out using a threshold that maximized the true skill statistic (TSS) to generate the most accurate predictions (Jiménez-Valverde and Lobo, 2007).

\section{RESULTS}

\section{Chlorotype diversity}

A total of 12 cpDNA haplotypes were found in the investigated populations (Table 4). All neighboring chlorotypes were linked by a single mutation (Fig. 1), except for $\mathrm{G}$ and $\mathrm{H}$ (separated by two mutations). Thus, the MST topology did not allow the division of chlorotypes into clearly demarcated groups separated by more than one mutation.

Chlorotypes did not show equal frequencies in overall sampling (Table 4). The most widely represented was chlorotype J, present in $26.4 \%$ of the samples analyzed. Chlorotypes E, F and G had a share of $15.47 \%, 12.19 \%$ and $12.11 \%$ respectively. The share of the remaining chlorotypes in the overall sampling was significantly lower than $10 \%$.

Chlorotypes E and $\mathrm{J}$ were the most widespread geographically (Fig. 2), with their occurrence established respectively in 6 and 5 out of the 8 investigated geographical regions. Most of the haplotypes occupying tips and terminal branches of the MST were more localized geographically. Chlorotype B, C and $\mathrm{H}$ have been found only in the Bohemian Forest, chlorotype D in the Harz Mts., while chlorotype H only in the Eastern Carpathians (Fig. 2). Chlorotype $\mathrm{G}$ was found almost exclusively in the Eastern Carpathians, while chlorotype $\mathrm{F}$ showed a predominant occurrence in the Western Carpathians as well as in the geographically close region of the Northern Carpathian Foreland.

Genetic diversity indices: chlorotypic richness $\left(\mathrm{A}_{\mathrm{Sc}}\right)$ and chlorotype diversity index $\left(\mathrm{H}_{\mathrm{Sd}}\right)$ were calculated for each investigated population. They varied broadly from 1 to 4.983 for $\mathrm{A}_{\mathrm{Sc}}$ and from 0 to 0.893 for $\mathrm{H}_{\mathrm{Sd}}$ (Table 4). We also examined geographical pattern of variation in chlorotypic richness. As shown in Fig. 3, populations with a high level of genetic diversity were co-located in the Bavarian Forest, the Harz Mts. and in the Western Carpathians (Tatra Mts.).

Also we compared genetic diversity indices between different geographical regions (Table 5). As expected, geographical regions differed substantially in terms of genetic diversity. Three regions: Western Carpathians, Harz Mts. and Bohemian Forest were found to be most diverse. The lowest genetic diversity was found in the Alps and in the Sudetes.

\section{Genetic structure}

The clustering approach employed in the present study (spherical k-means clustering SKMC) enabled us to study the structure present in our dataset on several levels. We examined a broad spectrum of different $\mathrm{k}$ values from $\mathrm{k}=2$ to $\mathrm{k}=25$. The results of SKMC from $\mathrm{k}=2$ to $\mathrm{k}=10$ were plotted on the map (Supplemental Information 5). Clearly, the populations from Eastern Carpathians formed one stable cluster (present in all the $\mathrm{k}$ 
levels), that differed from all the other populations. A subdivision of the populations into 6 clusters (Fig. 4) was statistically optimal (Fig. 5A) and had a high support in AMOVA (Fig. 5B). We carried out separate AMOVA analyses to test the distribution of genetic variance within and between groups identified by SKMC. Results of SKMC evidenced the presence of some level of genetic admixture in almost all studied geographical regions except in the Harz Mts., the Alps, and the Eastern Carpathians.

AMOVA performed without grouping populations showed that $79.16 \%$ of the total genetic variation was found between populations (Table 6). When assuming six groups of populations (according to k-means clustering), as much as $65.8 \%$ of the total variation was observed between groups of populations, whereas $15.82 \%$ was found among populations within groups (Table 6). These percentages of genetic variation were $42.88 \%$ and $37.90 \%$, respectively, when assuming seven groups (characterised according to the geographical regions sampled; Table 6). Separate AMOVAs performed within each investigated geographical region revealed the highest percentage of amongpopulation variation in the Sudetes and the Bohemian Forest: $85.66 \%$ and $74.57 \%$, respectively (Table 6). The lowest values of among-population variation was found in the Alps, where we recorded the presence of just one chlorotype (0\%; Table 6), and in the Harz Mts. (18.55\%; Table 6). All the remaining geographic regions showed intermediate level of among-population variation.

\section{Distribution modelling}

Model performance was assessed using two different statistics: True Skill Statistic (TSS) and Area under Receiver Operating Characteristic (ROC). All models performed well and had TSS $>0.7$ and ROC $>0.88$. The performance of two models CTA and FDA was weaker than the performance of the remaining methods, but still of acceptable quality.

Two (CCSM4, MPI ESM) out of the three climatic models suggest that the species survived the LGM (ca. $22 \mathrm{kyr}$ BP) only in the southernmost part of the Carpathians (Fig. 6). The Dinaric Alps and Balkan Mts. were also among the potential areas for species survival in southern Europe during the LGM (Fig. 6). Vast areas north from the Alps can be also considered as suitable for the survival of A. halleri (Fig. 6).

We also analysed the potential distribution of $A$. halleri during the Holocene climatic optimum (ca. $6 \mathrm{kyr}$ BP). Our models showed that recolonization must have advanced very slowly in the Carpathians, when compared with areas north of the Alps. All the models showed that conditions facilitating the spread of A. halleri occurred much earlier in between the Western Carpathians, the Sudetes and areas north from the Alps, while suitable areas in the Eastern Carpathians were at first much more restricted (Fig. 6).

\section{DISCUSSION}

\section{Carpathian populations of $\boldsymbol{A}$. halleri}

Our data suggest a clear differentiation among populations from western and eastern part of the Carpathians. Those population groups differ in terms of chlorotype composition and frequencies. The same differentiation also appears clearly in the SKMC analysis since the western and eastern populations were grouped in different clusters from $\mathrm{k}=2$. This pattern of genetic variation seems to follow the division between the eastern and western part of the Carpathians which was first recognized by Wołoszczak (Wołoszczak, 
1896) and was established on the basis of floristic data. The nature of the barrier between the western and eastern part of Carpathians has been the subject of many studies employing different methodologies from floristic (Pax, 1898; Jasiewicz, 1965)to cytologic (Mráz and Szelag, 2004) and genetic (Mráz et al., 2007; Ronikier et al., 2008a; Těšitel et al., 2009). It has been hypothesized that specific climatic and orographic conditions of the westernmost part of Bieszczady Mts. (also known as Bukovske Vrchy Mountains) are among the main factors influencing the genetic landscape of this part of Carpathians (Domin, 1940). It seems that results of our study may suggest that differentiation between western and eastern part of Carpathians may be a historical phenomenon connected with recolonisation of the area by plants that survived in different refugia. In this case we do not need to postulate the presence of a specific barrier responsible for the existence of genetic discontinuity between western and eastern part of Carpathians since this phenomenon could be also explained by colonisation from two different directions together with the presence of gene flow between the two groups as was evidenced by our study (i.e. the presence of haplotype $\mathrm{P}$ in western and eastern Carpathians).

The Eastern Carpathian populations are characterized by the presence of haplotype G, at very high frequencies. This haplotype was considered as ancestral by Pauwels (Pauwels et al., 2005). The presence of the ancestral haplotype $\mathrm{G}$ at high frequencies has also been recorded in populations located south of the Alps as well as in the south-eastern part of this mountain range (Pauwels et al., 2012). Our genetic data showing low genetic diversity in the Eastern Carpathians suggest relatively recent recolonisation of this area by $A$. halleri as was also indicated by the modelling experiments. This is surprising, when we take into account that several studies have demonstrated (with high probablity) that a glacial refugium existed in the Eastern Carpathians (Willis and Van Andel, 2004; Tollefsrud et al., 2008). The low genetic diversity in the Eastern Carpathians was, however, also confirmed by Tollefsrud et al. (2008) in Picea abies. These authors suggested a genetic bottleneck as a result of substantial decrease in population size as a reason of this phenomenon. The same scenario cannot be ruled out for A.halleri, although modelling experiments carried out during the present study suggest postglacial recolonisation as a more plausible explanation of low genetic diversity in the Eastern Carpathians.

The Western Carpathian populations are characterized by high levels of genetic diversity and the presence of a private haplotype $\mathrm{F}$ at high frequencies. Both premises suggest the possibility of in situ glacial survival of the species in the Western Carpathians.

Survival of plant species in the Western Carpathians during the LGM has been a focal point of many studies employing different methodologies. These works have shown that the existence of a Western Carpathian refugium is quite probable for many plant species, including mountain plants. Macrofossil charcoal fragments found in Kraków, just about $30 \mathrm{~km}$ in a straight line from population PL8 and about $40 \mathrm{~km}$ from PL 7, indicate full glacial presence of Pinus, Larix and Abies from 26 to $28 \mathrm{kyr}$ BP - during the coldest period of LGM that spanned between ca. 36 - 16 kyr BP (Damblon et al., 1996; Willis and Van Andel, 2004; Musil, 2003). Dates from humic soil further down in the sequence are even earlier, and indicate the presence of trees as early as $36 \mathrm{kyr}$ BP (Willis and Van Andel, 2004). There is also taxonomic evidence supporting the hypothesis of longstanding survival of different plant species in the Western Carpathians. 
Saxifraga wahlenbergii Ball. and Delphinium oxysepalum Borb. et Pax are good examples here. These two species are endemic to the Western Carpathians and occupy isolated systematic positions, what suggests that they are both of Tertiary age (Mirek and Piekos-Mirkowa, 1992). The survival of common yew (Taxus baccata), was also documented in charcoal for Moravany in Slovakia with a radiocarbon date of ca. $18 \mathrm{kyr}$ BP (Lityńska-Zając, 1995). There is also a large body of phylogeographic evidence that indicates the existence of a major northern refugium for a variety of animal taxa in the area around the Carpathians, with some lineages predating LGM (Provan and Bennett, 2008).

On the other hand, results of niche modelling conducted during the present study suggest postglacial recolonization of the area. In this scenario high genetic diversity in the area could be at least partially explained by relatively recent gene flow (occurring later than $6 \mathrm{kyr}$ BP, according to our modelling experiments) from the Eastern Carpathians. The presence of a genetic admixture in Western Carpathian populations was also revealed by Pauwels et al. (2012) in A. halleri and by Těšitel et al. (2009) in Melampurum sylvaticum. It seems that the question of the existence of glacial refugium for A.halleri in the Western Carpathians should remain open taking into account that evidence are still not conclusive.

In the SKMC analysis, populations from the Western Carpathians were clustered together with populations from upland regions of southern Poland. This fact supports the hypothesis of a Western Carpathian origin of populations located north of the Western Carpathians. However, for the reasons stated above, it is very difficult to say when these populations were founded. We have shown that populations of $A$. halleri in western and eastern part of Carpathians form two different genetic groups. It might be hypothesized that these groups could be derived from two different refugia. Populations in the Eastern Carpathians might belong to the group that survived in a southern refugium (areas south of the Alps, Dinaric Alps and Balkan Mts.) as suggested by Pauwels et al. (2012).

\section{Genetic differentiation between the Harz, the Bohemian Forest and the Alps}

The situation in the areas north and north-east of the Alps is more complex than in the Carpathians. SKMC analysis showed that at least two groups of populations can be recognized regardless of the level of k: populations from the Harz Mountains and from the Alps. Populations from the Bohemian Forest were usually assigned to different clusters, forming very heterogeneous group. This heterogeneity was also evidenced in AMOVA.

Differentiation is also apparent between the regions of the Harz Mts. and the Bohemian Forest, with the first harbouring haplotype $\mathrm{D}$, which is not present in the Bohemian Forest. In the latter region the occurrence of haplotype $C$ can be observed, which, in turn, is present neither in the Harz, nor in the Alps or the Šumava. A relatively recent (postglacial) origin of this differentiation could be hypothesized as both haplotypes occupy external nodes of the MST tree.

It is not easy to explain this pattern of genetic differentiation. Some ideas might be provided by the results published by Tollefsrud et al. (2008). Investigating the genetic variation of Norway Spruce together with pollen data they established that one possible glacial refugium of the species might have extended from the northern slopes of the 
Alps up to the Šmava (the Bohemian Massif). It seems that $A$. halleri might have also survived in a vast area, and that its Pleistocene distribution covered not only the region mentioned above, but also extended northwards and westwards to the Ardennes and Hautes Fagnes (High Fens) in Belgium. So far one natural population from this area has been tested by Pauwels et al. (2008). This, nowadays isolated, population from Hautes Fagnes, harbouring a chlorotype with an extremely restricted geographical range (Pauwels et al., 2008), might be the trace of a past A. halleri distribution in Western Europe. The vast extent of possible refugial areas north of the Alps was also clearly evidenced by our modelling experiments. Other studies based on molecular methods also suggest the presence of a glacial refugium in the Central Europe (Reisch et al., 2003; Koch, 2002; Rejzková et al., 2008)

Genetic variation in the closely related species Arabidopsis lyrata from the Harz, southern Germany and the Alps (Clauss and Mitchell-Olds, 2006), can give us some insights into a possible explanation of this pattern. Studies on genetic variation of A. lyrata (carried out on the basis of nuclear microsatellite loci) showed high within-population diversity throughout central Europe, accompanied by low regional differentiation and geographically widespread polymorphism. The authors hypothesized that (given the unlikeliness of gene flow) a common gene pool must have existed for central European populations (Koch and Matschinger, 2007). It should be noted that "central European" in this case is not a precise term and describes sites located approximately between the 10th and 16th eastern meridian. This area corresponds to the locations of the populations sampled by us north of the Alps in the the Bohemian Forest and the Harz. The same scenario is also probable for A. halleri, where haplotype $\mathrm{E}$, present in all regions north of the Alps, can be interpreted as a testimony to a common gene pool in the past. Other haplotypes, with restricted geographical range, would be, under this model, local derivatives that evolved after climatic warming and fragmentation of a previously vast range.

The Bohemian Forest hosts a population with the highest genetic diversity in the whole sampled area. The question whether this high genetic diversity should be attributed to the existence of a glacial refugium in this region or the presence of a contact zone between eastern and western lineages remains open. We think that results cited above (Clauss and Mitchell-Olds, 2006; Tollefsrud et al., 2008) as well as data clearly suggesting the presence of a glacial refugium for Fagus in the southern part of Czech Republic (Magri et al., 2006) make the hypothesis of the existence of a glacial refugium in this area more probable. The fact that even nowadays the range of A.halleri and Norway Spruce in Central Europe is highly similar (Tollefsrud et al., 2008) also suggest this scenario. However, no palaeobotanical data are available for A. halleri. Therefore, such a hypothesis cannot be fully confirmed or rejected. It should be also noted that the area between the 10th and 16th eastern meridian has been identified as a contact zone for some plant species (Fjellheim et al., 2006; Daneck et al., 2011). It is clear that further detailed studies in this region, also including other taxa, are needed to clarify these findings more precisely.

\section{Origin of $A$. halleri populations in the Sudetes}

We have shown that $A$. halleri populations in Sudetes are characterized by a very low genetic variation, with most of the populations harbouring only one cpDNA haplotype. 
This finding is not surprising, given the evidence from geological research showing that this region was severely impacted during the glacial period. Is seems that at least one glacial maximum (48-43 kyr BP) had a devastating effect on the regional flora, mainly due to the close proximity of the continental ice sheet (Marks, 2005). Geological evidence show that even during LGM this region was affected by the presence of the mountain glaciers Badura and Przybylski (1998). Therefore, it has been postulated that in situ glacial refugia, supporting the remains of the autochthonous flora, did not exist in the Sudetes (Mitka et al., 2007). Quite a different scenario involving survival on nunataks and in peripheral refugia has been suggested for the Alps (Stehlik, 2000). It is noteworthy that even nowadays the climate of the highest parts of the Sudetes is cold enough to maintain the occurrence of tundra-like ecosystems (Soukupova et al., 1995) . It seems therefore, that A. halleri populations in the Sudetes could be of a recent (postglacial) origin. This is supported by the very low genetic variation found in Sudetes as well as the fact that despite dense sampling, we have not found any chlorotypes specific to this area. On the basis of the evidence from cpDNA variation, it could be hypothesized that populations from the Bohemian Forest could be a source of migrants that established new populations of the species in this region after LGM.

We have also found the presence of haplotype I in high-mountain populations of A. halleri in the Sudetes. The occurrence of this uncommon haplotype has also been recorded in high-mountain populations in the Western Carpathians as well as for one population in the Bohemian Forest. A similar pattern have been also recognized in Pulsatilla vernalis (Ronikier et al., 2008b). The most reasonable explanation for the observed pattern is the assumption that a contact between the Sudetic and Carpathian flora occurred in the past. Mitka et al. (2007) suggested that this contact could have occurred especially for high-mountain taxa, which could easily disperse within the open landscapes that were present between the Sudetes and the Carpathians during glacial maxima. This supposition is also supported by the floristic evidence showing that several high-mountain taxa such as Erigeron macrophyllus Herbich, Melampyrum herbichii Woł., Sesleria tatrae (Degen) Deyl and Thymus carpathicus Čelak. that are present in the Carpathians, occur also in high-mountain environments of the Sudetes (Pawłowski, 1969). The connections between the Carpathian and Sudetic populations of A.halleri surely require further studies.

\section{Taxonomic concept of A.halleri in the Carpathians}

Taxonomy of A. halleri is still much debated and to date three European subspecies have been recognised: subsp. halleri, subsp. tatrica (Pawł.) Kolník, and subsp. dacica (Heuff.) Kolník (Hohmann et al., 2014). This division is based on a morphological study of the Carpathian populations published by Kolník and Marhold (2006). Our results seem to question this taxonomic division that has already been cited by various authors (Clauss and Mitchell-Olds, 2006; Koch et al., 2008). We have shown that main genetic groups identified by cpDNA variation are not consistent with the division proposed by Kolník and Marhold (2006), nor with the distribution of the described taxa. 


\section{CONCLUSIONS}

1. Genetic variation in A.halleri is strongly geographically structured within the investigated area and at least 6 clusters of populations can be identified on the basis of cpDNA variation.

2. There is a clear genetic differentiation within the Carpathian populations. Two distinct clusters of populations were identified in western and eastern part of the mountain range. It is clear that the two groups originated from two different glacial refugia. There are traces of gene flow between the two groups.

3. The possibility of the existence of a glacial refugium in the Western Carpathians and the Bohemian Forest cannot be ruled out on the basis of the present research but the evidence is not conclusive.

4. It seems that the area of Sudetes was colonised after LGM. Populations from the Bohemian Forest can be hypothesised as a source of the migrants which established A.halleri populations in the area.

\section{ACKNOWLEDGMENTS}

The authors would like to thank Prof. Ian C. Trueman (University of Wolverhampton, UK) for improving the English of the manuscript. Krkonošský národní park (CZ), Karkonoski Park Narodowy (PL), Tatrzański Park Narodowy (PL), Bieszczadzki Park Narodowy (PL) and Karpatskij biosfernij Zapovidnik (UA) are acknowledged for granting permits to collect plant samples within protected areas of these national parks.

\section{REFERENCES}

Al-Shehbaz, I. A. and O'Kane, S. L. (2002). Taxonomy and phylogeny of Arabidopsis (Brassicaceae). The Arabidopsis Book, 6(1):1.

Alvarez, N., Thiel-Egenter, C., Tribsch, A., Holderegger, R., Manel, S., Schönswetter, P., Taberlet, P., Brodbeck, S., Gaudeul, M., Gielly, L., Küpfer, P., Mansion, G., Negrini, R., Paun, O., Pellecchia, M., Rioux, D., Schüpfer, F., Van Loo, M., Winkler, M., and Gugerli, F. (2009). History or ecology? Substrate type as a major driver of spatial genetic structure in Alpine plants. Ecology Letters, 12(7):632-640.

Badura, J. and Przybylski, B. (1998). Zasięg lądolodów plejstoceńskich i deglacjacja obszaru pomiędzy Sudetami a Wałem Śląskim. Biuletyn Państwowego Instytutu Geologicznego, 385:9-28.

Barbet-Massin, M., Jiguet, F., Albert, C. H., and Thuiller, W. (2012). Selecting pseudoabsences for species distribution models: how, where and how many? Methods in Ecology and Evolution, 3(2):327-338.

Clauss, M. J. and Mitchell-Olds, T. (2006). Population genetic structure of Arabidopsis lyrata in Europe. Molecular Ecology, 15(10):2753-2766.

Damblon, F., Haesaerts, P., and Van der Plicht, J. (1996). New datings and considerations on the chronology of upper palaeolithic sites in the great eurasiatic plain. Prehistoire Europeenne, 9:177-231. 
Daneck, H., Abraham, V., Fér, T., and Marhold, K. (2011). Phylogeography of Lonicera nigra in Central Europe inferred from molecular and pollen evidence. Preslia, 83:237257.

Despres, L., Loriot, S., and Gaudeul, M. (2002). Geographic pattern of genetic variation in the European globeflower Trollius europaeus 1. (Ranunculaceae) inferred from amplified fragment length polymorphism markers. Molecular Ecology, 11(11):23372347.

Domin, K. (1940). O geobotanickem rozhranı Zapadnıch a Vychodnıch Karpat. Veda Prirodnı, 20:76-78.

Dormann, C. F. C., Elith, J., Bacher, S., Buchmann, C., Carl, G., Carré, G., Marquéz, J. R. G., Gruber, B., Lafourcade, B., Leitão, P. J., Münkemüller, T., Mcclean, C., Osborne, P. E., Reineking, B., Schröder, B., Skidmore, A. K., Zurell, D., and Lautenbach, S. (2013). Collinearity: a review of methods to deal with it and a simulation study evaluating their performance. Ecography, 36:27-46.

Ehlers, J., Eissmann, L., Lippstreu, L., Stephan, H.-J., and Wansa, S. (2004). Quaternary Glaciations Extent and Chronology - Part I: Europe, volume 2.

El Mousadik, A. and Petit, R. (1996). High level of genetic differentiation for allelic richness among populations of the argan tree endemic to Morocco. Theoretical and Applied Genetics, pages 832-839.

Excoffier, L., Laval, G., and Schneider, S. (2005). Arlequin ver. 3.0: An integrated software package for population genetics data analysis. Evolutionary Bioinformatics Online, 1(1):47-50.

Excoffier, L. and Smouse, P. E. (1994). Using allele frequencies and geographic subdivision to reconstruct gene trees within a species: Molecular variance parsimony. Genetics, 136:343-359.

Fjellheim, S., Rognli, O. A., Fosnes, K., and Brochmann, C. (2006). Phylogeographical history of the widespread meadow fescue (Festuca pratensis huds.) inferred from chloroplast dna sequences. Journal of Biogeography, 33(0318):1470-1478.

Goudet, J. (2013). FSTAT: a computer program to calculate F-Statistics. Journal of Heredity, 104:586-590.

Hewitt, G. (1999). Post-glacial re-colonization of European biota. Biological Journal of the Linnean Society, 68(1-2):87-112.

Hewitt, G. M. (2000). The genetic legacy of the quarternary ice ages. Nature, 405:907913.

Hewitt, G. M. (2004). Genetic consequences of climatic oscillations in the Quaternary. Philosophical transactions of the Royal Society of London. Series B, Biological sciences, 359(1442):183-195.

Hijmans, R. J., Cameron, S. E., Parra, J. L., Jones, P. G., and Jarvis, A. (2005). Very high resolution interpolated climate surfaces for global land areas. International Journal of Climatology, 25(15):1965-1978.

Hill, M. O., Harrower, C. A., and Preston, C. D. (2013). Spherical k-means clustering is good for interpreting multivariate species occurrence data. Methods in Ecology and Evolution, 4(6):542-551.

Hohmann, N., Schmickl, R., Chiang, T.-Y., Lu Anová, M., Kolá, F., Marhold, K., and Koch, M. (2014). Taming the wild: resolving the gene pools of non-model Arabidopsis lineages. BMC Evolutionary Biology, 14(1):224. 
Jalas, J. and Suominen, J. (1994). Atlas Florae Europaeae. Distribution of Vascular Plants in Europe. 10. Cruciferae (Sisymbrium to Aubertia). The Committee for Mapping the Flora of Europe and Societas Biologica Fennica Vanamo.

Jasiewicz, A. (1965). Rośliny naczyniowe Bieszczadów Zachodnich. Monographiae Botanicae, 22:1-340.

Jiménez-Valverde, A. and Lobo, J. M. (2007). Threshold criteria for conversion of probability of species presence to either-or presence-absence. Acta Oecologica, 31(3):361-369.

Kalinowski, S. T. (2004). Counting alleles with rarefaction: Private alleles and hierarchical sampling designs. Conservation Genetics, 5(4):539-543.

Koch, M. (2002). Genetic differentiation and speciation in prealpine Cochlearia : Allohexaploid Cochlearia bavarica Vogt (Brassicaceae) compared to its diploid ancestor Cochlearia pyrenaica DC. in Germany and Austria. Plant Systematics and Evolution, 232(1-2):35-49.

Koch, M. and Matschinger, M. (2007). Evolution and genetic differentiation among relatives of Arabidopsis thaliana. Proceedings of the National Academy of Sciences of the United States of America, 104(15):6272-6277.

Koch, M., Wernisch, M., and Schmickl, R. (2008). Arabidopsis thaliana's wild relatives: An updated overview on systematics, taxonomy and evolution. Taxon, 57(3):933-943.

Kolník, M. and Marhold, K. (2006). Distribution, chromosome numbers and nomenclature conspect of Arabidopsis halleri (Brassicaceae) in the Carpathians. Biologia, 61(1):41-50.

Lityńska-Zając, M. (1995). Anthracological analysis. In Hromada, J. and Kozłowski, J., editors, Complex of Upper Palaeolithic sites near Moravany Western Slovakia, pages 74-79. Wydawnictwo Uniwersytetu Jagiellońskiego.

Llaurens, V., Castric, V., Austerlitz, F., and Vekemans, X. (2008). High paternal diversity in the self-incompatible herb Arabidopsis halleri despite clonal reproduction and spatially restricted pollen dispersal. Molecular Ecology, 17(6):1577-1588.

Magri, D., Vendramin, G. G., Comps, B., Dupanloup, I., Geburek, T., Gömöry, D., Latałowa, M., Litt, T., Paule, L., Roure, J. M., Tantau, I., Van Der Knaap, W. O., Petit, R. J., and De Beaulieu, J. L. (2006). A new scenario for the Quaternary history of European beech populations: Palaeobotanical evidence and genetic consequences. New Phytologist, 171(1):199-221.

Marks, M. (2005). Pleistocene glacial limits in the territory of Poland. Przeglad Geologiczny, 53:988-993.

Médail, F. and Diadema, K. (2009). Glacial refugia influence plant diversity patterns in the Mediterranean basin. Journal of Biogeography, 36(7):1333-1345.

Mirek, Z. and Piekos-Mirkowa, H. (1992). Flora and vegetation of the Polish Tatra Mountains. Mountain Research and Development, 12(2):147-173.

Mitka, J., Sutkowska, A., Ilnicki, T., and Joachmiak, A. (2007). Reticulate evolution of high-alpine Aconitum (Ranunculaceae) in the Eastern Sudetes and Western Carpathians (Central Europe). Acta Botanica Cracoviensia Series Botanica, 49:15-26.

Mráz, P., Gaudeul, M., Rioux, D., Gielly, L., Choler, P., and Taberlet, P. (2007). Genetic structure of Hypochaeris uniflora (Asteraceae) suggests vicariance in the Carpathians and rapid post-glacial colonization of the Alps from an eastern Alpine refugium. Journal of Biogeography, 34(12):2100-2114. 
Mráz, P. and Szelag, Z. (2004). Chromosome numbers and reproductive systems in selected species of Hieracium and Pilosella (Asteraceae) from romania. Annales Botanici Fennici, 41(December):405-414.

Musil, R. (2003). The middle and upper palaeolithic game suite in Central and SouthEastern Europe. In van Andel, T. and Davies, S., editors, Neanderthals and Modern Humans in the European Landscape during the Last Glaciation, pages 167-190. McDonald Institute for Archaeological Research.

Nei, M. (1987). Molecular evolutionary genetics. Columbia University Press.

Oetting, W. S., Lee, H. K., Flanders, D. J., Wiesner, G. L., Sellers, T. a., and King, R. a. (1995). Linkage analysis with multiplexed short tandem repeat polymorphisms using infrared fluorescence and $\mathrm{m} 13$ tailed primers. Genomics, 30:450-458.

Pauwels, M., Saumitou-Laprade, P., Holl, A. C., Petit, D., and Bonnin, I. (2005). Multiple origin of metallicolous populations of the pseudometallophyte Arabidopsis halleri (Brassicaceae) in central Europe: The cpDNA testimony. Molecular Ecology, 14(14):4403-4414.

Pauwels, M., Vekemans, X., Godé, C., Frérot, H., Castric, V., and Saumitou-Laprade, P. (2012). Nuclear and chloroplast DNA phylogeography reveals vicariance among European populations of the model species for the study of metal tolerance, Arabidopsis halleri (Brassicaceae). New Phytologist, 193(4):916-928.

Pauwels, M., Willems, G., Roosens, N., Frérot, H., and Saumitou-Laprade, P. (2008). Merging methods in molecular and ecological genetics to study the adaptation of plants to anthropogenic metal-polluted sites: implications for phytoremediation. Molecular ecology, 17(1):108-19.

Pawłowski, B. (1969). Die Karpaten und die Sudeten - eine vergleichende pflanzengeographische Studie. Archivum für Naturschutz und Landschaftsforschung, 9:251263.

Pax, F. (1898). Grundzuge der Pflanzenverbreitung in der Karpaten. Verlag von Wilhelm Engelmann.

Phillips, S. J., Anderson, R. P., and Schapire, R. E. (2006). Maximum entropy modeling of species geographic distributions. Ecological Modelling, 190(3-4):231-259.

Posada, D. and Crandall, K. A. (2001). Intraspecific gene genealogies: trees grafting into networks. Trends in Ecology and Evolution, 16(1):37-45.

Provan, J. and Bennett, K. D. (2008). Phylogeographic insights into cryptic glacial refugia. Trends in Ecology and Evolution, 23(10):564-571.

Reisch, C., Poschlod, P., and Wingender, R. (2003). Genetic variation of Saxifraga paniculata Mill. (Saxifragaceae): Molecular evidence for glacial relict endemism in Central Europe. Biological Journal of the Linnean Society, 80(1):11-21.

Rejzková, E., Fér, T., Vojta, J., and Marhold, K. (2008). Phylogeography of the forest herb Carex pilosa (Cyperaceae). Botanical Journal of the Linnean Society, 158:115130.

Rohlf, F. (1973). Algorithm 76: Hierarchical clustering using the minimum spanning tree. Computer Journal, 16:93-95.

Ronikier, M. (2011). Biogeography of high-mountain plants in the Carpathians: An emerging phylogeographical perspective. Taxon, 60(2):373-389.

Ronikier, M., Cieślak, E., and Korbecka, G. (2008a). High genetic differentiation in the alpine plant Campanula alpina Jacq. (Campanulaceae): Evidence for glacial survival 
in several Carpathian regions and long-term isolation between the Carpathians and the Alps. Molecular Ecology, 17(7):1763-1775.

Ronikier, M., Costa, A., Aguilar, J. F., Feliner, G. N., Küpfer, P., and Mirek, Z. (2008b). Phylogeography of Pulsatilla vernalis (L.) Mill. (Ranunculaceae): Chloroplast DNA reveals two evolutionary lineages across Central Europe and Scandinavia. Journal of Biogeography, 35(9):1650-1664.

Schönswetter, P., Stehlik, I., Holderegger, R., and Tribsch, A. (2005). Molecular evidence for glacial refugia of mountain plants in the European Alps. Molecular Ecology, 14(11):3547-3555.

Soukupova, L., Kocianova, M., Jenik, J., and Sekyra, J. (1995). Artic-alpine tundra of the Krkonose, the Sudetes. Opera Corcontica, 32:5-88.

Stachurska-Swakoń, A., Cieślak, E., and Ronikier, M. (2013). Phylogeography of a subalpine tall-herb Ranunculus platanifolius (Ranunculaceae) reveals two main genetic lineages in the European mountains. Botanical Journal of the Linnean Society, 171(2):413-428.

Stehlik, I. (2000). Nunataks and peripheral refugia for alpine plants during quaternary glaciation in the middle part of the Alps. Botanica Helvetica, 110(1):25-30.

Stewart, J. R. and Lister, A. M. (2001). Cryptic northern refugia and the origins of the modern biota. Trends in Ecology and Evolution, 16(11):608-613.

Taberlet, P., Fumagalli, L., Wust-Saucy, A. G., and Cosson, J. F. (1998). Comparative phylogeography and postglacial colonization routes in Europe. Molecular Ecology, 7(4):453-464.

Thuiller, W. (2014). Editorial commentary on "Biomod - optimizing predictions of species 17 distributions and projecting potential future shifts under global change". Global Change Biology, 20:3591-3592.

Thuiller, W., Lafourcade, B., Engler, R., and Araújo, M. B. (2009). Biomod - a platform for ensemble forecasting of species distributions. Ecography, 32(3):369-373.

Tollefsrud, M. M., Kissling, R., Gugerli, F., Johnsen, Ø., Skrøppa, T., Cheddadi, R., Van Der Knaap, W. O., Latałowa, M., Terhürne-Berson, R., Litt, T., Geburek, T., Brochmann, C., and Sperisen, C. (2008). Genetic consequences of glacial survival and postglacial colonization in Norway spruce: Combined analysis of mitochondrial dna and fossil pollen. Molecular Ecology, 17(18):4134-4150.

Tribsch, A. and Schönswetter, P. (2003). In search for Pleistocene refugia for mountain plants: patterns of endemism and comparative phylogeography confirm palaeoenvironmental evidence in the Eastern European Alps. Taxon, 52:477-497.

Těšitel, J., Malinova, T., Stech, M., Herbstova, M., Malinová, T., Štech, M., and Herbstová, M. (2009). Variation in the Melampyrum sylvaticum group in the Carpathian and Hercynian region: two lineages with different evolutionary histories. Preslia, 81(1):1-22.

Van Rossum, F., Bonnin, I., Fénart, S., Pauwels, M., Petit, D., and Saumitou-Laprade, P. (2004). Spatial genetic structure within a metallicolous population of Arabidopsis halleri, a clonal, self-incompatible and heavy-metal-tolerant species. Molecular Ecology, 13(10):2959-2967.

Willis, K. J. and Van Andel, T. H. (2004). Trees or no trees? the environments of Central and Eastern Europe during the Last Glaciation. Quaternary Science Reviews, 23(23-24):2369-2387. 
732 Wołoszczak, E. (1896). Z granicy flory zachodnio- i wschodniokarpackiej. Sprawozdanie 733 Komisji Fizjograficznej, 31:119-159. 


\section{Table 1 (on next page)}

Location of sampled populations and sample sizes.

$\mathrm{n}$ - sample size 


\begin{tabular}{|c|c|c|c|c|c|}
\hline & & \multicolumn{2}{|c|}{ GPS coordinates } & \multirow{2}{*}{$\begin{array}{c}\text { altitude } \\
\text { (m a.s.l.) }\end{array}$} & \multirow[b]{2}{*}{$\mathrm{n}$} \\
\hline Population & Locality; collectors & latitude & longitude & & \\
\hline A05 & Mutters, Alps, Northern Tyrol, Austria; MP, PSL & $47^{\circ} 13^{\prime} 46.68^{\prime \prime}$ & $11^{\circ} 22^{\prime} 46.72^{\prime}{ }^{\prime}$ & 807 & 14 \\
\hline A08 & W from Mehrn, Alps, Northern Tyrol, Austria; MP, PSL & $47^{\circ} 25^{\prime} 10.56^{\prime \prime}$ & $11^{\circ} 51^{\prime} 57.46^{\prime \prime}$ & 522 & 45 \\
\hline A09 & W from Mehrn, Alps, Northern Tyrol, Austria; MP, PSL & $47^{\circ} 25^{\prime} 14.57^{\prime \prime}$ & $11^{\circ} 51^{\prime} 53.71^{\prime \prime}$ & 519 & 20 \\
\hline CZ04 & SW from Vimperk, Bohemian Forest, Czech Rep.; MP, PSL & $49^{\circ} 02^{\prime} 08.72^{\prime}$ & $13^{\circ} 45^{\prime} 08.41^{\prime \prime}$ & 772 & 14 \\
\hline $\mathrm{CZ05}$ & N from Kubova Hut', Bohemian Forest, Czech Rep.; MP, PSL & $48^{\circ} 59^{\prime} 15.54^{\prime \prime}$ & $13^{\circ} 46^{\prime} 23.40^{\prime \prime}$ & 998 & 24 \\
\hline CZ06 & Kubova Hut', Bohemian Forest, Czech Rep.; MP, PSL & $48^{\circ} 59^{\prime} 00.00^{\prime \prime}$ & $13^{\circ} 46^{\prime} 00.00^{\prime \prime}$ & 1060 & 12 \\
\hline $\mathrm{CZ14}$ & near Starý Herštajn, Bohemian Forest, Czech Rep.; MP, PSL & $49^{\circ} 28^{\prime} 37.19^{\prime \prime}$ & $12^{\circ} 42^{\prime} 92.15^{\prime \prime}$ & 842 & 20 \\
\hline CZ16 & Horská Kvilda, Bohemian Forest, Czech Rep.; MP, PSL & $49^{\circ} 03^{\prime} 21.05^{\prime \prime}$ & $13^{\circ} 33^{\prime} 18.19^{\prime \prime}$ & 1052 & 57 \\
\hline $\mathrm{CZ18}$ & NW from Zhuři, Bohemian Forest, Czech Rep.; MP, PSL & $49^{\circ} 05^{\prime} 42.14^{\prime \prime}$ & $13^{\circ} 32^{\prime} 10.31^{\prime \prime}$ & 1039 & 9 \\
\hline $\mathrm{CZ20}$ & Labská, Sudetes, Czech Rep.; PW, EPW & $50^{\circ} 42^{\prime} 55.9^{\prime \prime}$ & $15^{\circ} 35^{\prime} 00.9^{\prime}$, & 698 & 33 \\
\hline $\mathrm{CZ21}$ & Herlikovice, Sudetes, Czech Rep.; PW, EPW & $50^{\circ} 39^{\prime} 41.6^{\prime \prime}$ & $15^{\circ} 35^{\prime} 44.5^{\prime \prime}$ & 555 & 30 \\
\hline $\mathrm{CZ22}$ & Rýchorská Bouda, Sudetes, Czech Rep.; PW, EPW & $50^{\circ} 39^{\prime} 29.4^{\prime \prime}$ & $15^{\circ} 51^{\prime} 00,00^{\prime \prime}$ & 995 & 32 \\
\hline D01 & NE from Ramspau, Bohemian Forest, Germany; MP, PSL & $49^{\circ} 10^{\prime} 06.40^{\prime \prime}$ & $12^{\circ} 09^{\prime} 08.80^{\prime}$ & 345 & 7 \\
\hline D02 & near Hirschling, Bohemian Forest, Germany; MP, PSL & $49^{\circ} 11^{\prime} 31.00^{\prime \prime}$ & $12^{\circ} 09^{\prime} 52.00^{\prime \prime}$ & 452 & 8 \\
\hline D03 & W from Cham, Bohemian Forest, Germany; MP, PSL & $49^{\circ} 13^{\prime} 10.00^{\prime \prime}$ & $12^{\circ} 39^{\prime} 66.00^{\prime \prime}$ & 362 & 9 \\
\hline D04 & S from Hochfeld, Bohemian Forest, Germany; MP, PSL & $49^{\circ} 09^{\prime} 50.95^{\prime \prime}$ & $12^{\circ} 47^{\prime} 45.43^{\prime \prime}$ & 383 & 11 \\
\hline D08 & S from Oker, Harz Mts., Germany; MP, PSL & $51^{\circ} 53^{\prime} 47.45^{\prime \prime}$ & $10^{\circ} 29^{\prime} 23.97^{\prime \prime}$ & 279 & 12 \\
\hline D09 & S from Glosar, Harz Mts., Germany; MP, PSL & $51^{\circ} 53^{\prime} 27.55^{\prime \prime}$ & $10^{\circ} 25^{\prime} 05.62^{\prime \prime}$ & 325 & 18 \\
\hline D11 & E from Hahnemklee, Harz Mts., Germany; MP, PSL & $51^{\circ} 51^{\prime} 16.17^{\prime \prime}$ & $10^{\circ} 21^{\prime} 56.68^{\prime \prime}$ & 644 & 18 \\
\hline D12 & SE from Lautenthal, Harz Mts., Germany; MP, PSL & $51^{\circ} 51^{\prime} 54.09^{\prime \prime}$ & $10^{\circ} 17^{\prime} 53.85^{\prime \prime}$ & 415 & 18 \\
\hline D13 & SW from Langelsheim, Harz Mts., Germany; MP, PSL & $51^{\circ} 55^{\prime} 13.40^{\prime \prime}$ & $10^{\circ} 18^{\prime} 29.68^{\prime \prime}$ & 231 & 20 \\
\hline D14 & SE from Heersum, Harz Mts., Germany; MP, PSL & $52^{\circ} 06^{\prime} 08.66^{\prime \prime}$ & $10^{\circ} 06^{\prime} 57.62^{\prime \prime}$ & 89 & 11 \\
\hline PL02 & Żyglinek, Western Carpathian Foreland, Poland; MP, PSL & $50^{\circ} 29^{\prime} 40.81^{\prime \prime}$ & $18^{\circ} 56^{\prime} 40.29^{\prime \prime}$ & 298 & 21 \\
\hline PL03 & W from Żyglinek, Western Carpathian Foreland, Poland; MP, PSL & $50^{\circ} 29^{\prime} 30.34^{\prime \prime}$ & $18^{\circ} 57^{\prime} 34.57^{\prime \prime}$ & 302 & 15 \\
\hline PL07 & Ujków Stary, Western Carpathian Foreland, MP, PSL & $50^{\circ} 17^{\prime} 00.92^{\prime \prime}$ & $19^{\circ} 29^{\prime} 03.10^{\prime \prime}$ & 325 & 19 \\
\hline PL08 & N from Chobot, Western Carpathian Foreland, Poland; MP, PSL & $50^{\circ} 05^{\prime} 51.87^{\prime \prime}$ & $20^{\circ} 22^{\prime} 32.89^{\prime \prime}$ & 193 & 12 \\
\hline PL32 & Kościelisko, Western Carpathians, Poland; AK & $49^{\circ} 16^{\prime} 27.72^{\prime \prime}$ & $19^{\circ} 52^{\prime} 45.58^{\prime \prime}$ & 990 & 27 \\
\hline PL33 & Zakopane, Western Carpathians, Poland; AK & $49^{\circ} 17^{\prime} 34.02^{\prime \prime}$ & $19^{\circ} 55^{\prime} 34.59^{\prime \prime}$ & 879 & 21 \\
\hline PL37 & Szklarska Poręba, Sudetes, Poland; PW, EPW & $50^{\circ} 49^{\prime} 08.50^{\prime}$ & $15^{\circ} 31^{\prime} 24.08^{\prime \prime}$ & 690 & 40 \\
\hline PL38 & Orle, Sudetes, Poland; PW, EPW & $50^{\circ} 49^{\prime} 00.59^{\prime \prime}$ & $15^{\circ} 22^{\prime} 51.85^{\prime \prime}$ & 828 & 29 \\
\hline PL39 & E from Kowary, Sudetes, Poland; PW, EPW & $50^{\circ} 47^{\prime} 23.66^{\prime \prime}$ & $15^{\circ} 51^{\prime} 55.82^{\prime \prime}$ & 583 & 39 \\
\hline PL40 & Kowarska Pass, Sudetes, Poland; PW, EPW & $50^{\circ} 45^{\prime} 37.77^{\prime}$ & $15^{\circ} 52^{\prime} 04.37^{\prime}$ & 729 & 39 \\
\hline PL41 & Hala Izerska, Sudetes, Poland; PW, EPW & $50^{\circ} 50^{\prime} 52.36^{\prime \prime}$ & $15^{\circ} 21^{\prime} 45.62^{\prime \prime}$ & 837 & 39 \\
\hline PL42 & Łabski Szczyt, Sudetes, Poland; PW, EPW & $50^{\circ} 47^{\prime} 14.47^{\prime \prime}$ & $15^{\circ} 32^{\prime} 17.18^{\prime \prime}$ & 1189 & 39 \\
\hline PL43 & Mały Staw, Sudetes, Poland; PW, EPW & $50^{\circ} 44^{\prime} 54.90^{\prime \prime}$ & $15^{\circ} 42^{\prime} 09.56^{\prime \prime}$ & 1199 & 39 \\
\hline PL44 & W from Zieleniec, Sudetes, Poland; PW, EPW & $50^{\circ} 22^{\prime} 54.28^{\prime \prime}$ & $16^{\circ} 21^{\prime} 47.26^{\prime \prime}$ & 755 & 41 \\
\hline PL45 & Zawadzkie, Western Carpathian Foreland, Poland; PW, EPW & $50^{\circ} 37^{\prime} 23.06^{\prime \prime}$ & $18^{\circ} 26^{\prime} 39.06^{\prime \prime}$ & 208 & 39 \\
\hline PL46 & Sianki, Eastern Carpathians, Poland; PW, EPW & $49^{\circ} 01^{\prime} 14.40^{\prime \prime}$ & $22^{\circ} 53^{\prime} 08.40^{\prime \prime}$ & 800 & 23 \\
\hline PL47 & Roztoki Górne, Eastern Carpathians, Poland; PW, EPW & $49^{\circ} 09^{\prime} 04.30^{\prime \prime}$ & $22^{\circ} 19^{\prime} 16.90^{\prime \prime}$ & 728 & 24 \\
\hline PL48 & Krzywe, Eastern Carpathians, Poland; PW, EPW & $49^{\circ} 11^{\prime} 64.00^{\prime \prime}$ & $22^{\circ} 21^{\prime} 28.80^{\prime \prime}$ & 647 & 20 \\
\hline PL49 & Nasiczne, Eastern Carpathians, Poland; PW, EPW & $49^{\circ} 10^{\prime} 22.90^{\prime \prime}$ & $22^{\circ} 35^{\prime} 50.80^{\prime \prime}$ & 643 & 22 \\
\hline PL50 & Łężyce, Sudetes, Poland; PW, EPW & $50^{\circ} 26^{\prime} 44.8^{\prime \prime}$ & $16^{\circ} 20^{\prime} 58.3^{\prime \prime}$ & 712 & 34 \\
\hline SK02 & Vysný Klátov, Western Carpathians, Slovakia; MP, PSL & $48^{\circ} 46^{\prime} 10.33^{\prime \prime}$ & $21^{\circ} 07^{\prime} 48.49^{\prime \prime}$ & 586 & 22 \\
\hline SK05 & NE from Javorina, Western Carpathians, Slovakia; MP, PSL & $49^{\circ} 16^{\prime} 59.11^{\prime \prime}$ & $20^{\circ} 09^{\prime} 14.51^{\prime \prime}$ & 994 & 46 \\
\hline SK10 & Štrbskié Pleso, Western Carpathians, Slovakia; PW, EPW & $49^{\circ} 07^{\prime} 07.26^{\prime \prime}$ & $20^{\circ} 03^{\prime} 42.24^{\prime \prime}$ & 1322 & 21 \\
\hline SK12 & Plihov, Western Carpathians, Slovakia; PW, EPW & 49²4'15.30’' & $20^{\circ} 42^{\prime} 08.52^{\prime \prime}$ & 466 & 16 \\
\hline UA01 & Rakhiv, Eastern Carpathians, Ukraine; PW, AR, PSL & $48^{\circ} 01^{\prime} 31.60^{\prime \prime}$ & $24^{\circ} 10^{\prime} 02.80^{\prime}$ & 434 & 31 \\
\hline UA02 & Kvasy, Eastern Carpathians, Ukraine; PW, AR, PSL & $48^{\circ} 07^{\prime} 59.00^{\prime \prime}$ & $24^{\circ} 16^{\prime} 26.10^{\prime \prime}$ & 530 & 32 \\
\hline UA04 & Vil'shany, Eastern Carpathians, Ukraine; PW, AR, PSL & $48^{\circ} 19^{\prime} 57.60^{\prime \prime}$ & $23^{\circ} 36^{\prime} 22.80^{\prime \prime}$ & 555 & 32 \\
\hline UA05 & Synevyr, Eastern Carpathians, Ukraine; PW, AR, PSL & $48^{\circ} 32^{\prime} 04.80^{\prime \prime}$ & $23^{\circ} 38^{\prime} 53.50^{\prime \prime}$ & 699 & 32 \\
\hline UA06 & Synevyr Lake, Eastern Carpathians, Ukraine; PW, AR, PSL & $48^{\circ} 37^{\prime} 01.20^{\prime \prime}$ & $23^{\circ} 41^{\prime} 10.20^{\prime \prime}$ & 1006 & 16 \\
\hline UA07 & Synevyrska Poliana, Eastern Carpathians, Ukraine; PW, AR, PSL & $48^{\circ} 36^{\prime} 00.60^{\prime \prime}$ & $23^{\circ} 41^{\prime} 54.30^{\prime \prime}$ & 829 & 8 \\
\hline
\end{tabular}




\section{Table 2 (on next page)}

cpDNA polymorphism observed in investigated material

Observed mutations were numbered from 1 to 12 (numbers correspond with those given in Fig. 1 and in Table 3) 


\begin{tabular}{|c|c|c|c|c|c|c|c|}
\hline \multirow[b]{2}{*}{ mutation number } & \multirow[b]{2}{*}{$\begin{array}{c}\text { RFLP } \\
\text { (PAUWELS I } \\
\text { IN. 2005) }\end{array}$} & \multirow[b]{2}{*}{$\begin{array}{l}\text { mutation } \\
\text { type }\end{array}$} & \multirow[b]{2}{*}{ methodology } & \multicolumn{2}{|r|}{ Allelic variation } & \multirow[b]{2}{*}{ 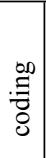 } & \multirow[b]{2}{*}{$\begin{array}{l}\text { fragment size } \\
\text { (bp) }\end{array}$} \\
\hline & & & & $\begin{array}{c}\text { base } \\
\text { detected } \\
\text { (SNaPshot) }\end{array}$ & polymorphism type & & \\
\hline \multirow{2}{*}{1} & \multirow{2}{*}{ K1K2 HpaII3 } & \multirow{2}{*}{ SNP } & \multirow{2}{*}{ SNaPshot } & A & ATCAGG & 1 & - \\
\hline & & & & $\mathrm{C}$ & ATCTGG & 9 & - \\
\hline \multirow{2}{*}{2} & \multirow{2}{*}{ K1K2 AscI3 } & \multirow{2}{*}{ SNP } & \multirow{2}{*}{ SNaPshot } & $\mathrm{T}$ & $A G G$ TAT & 1 & - \\
\hline & & & & A & $A G G \mathbf{A A T}$ & 9 & - \\
\hline \multirow{2}{*}{3} & \multirow{2}{*}{ K1K2 Tru915 } & \multirow{2}{*}{ SNP } & \multirow{2}{*}{ SNaPshot } & G & TTGAAT & 1 & - \\
\hline & & & & $\mathrm{T}$ & TTTAAT & 9 & - \\
\hline \multirow{2}{*}{4} & \multirow{2}{*}{ CS AluI1 } & \multirow{2}{*}{ SNP } & \multirow{2}{*}{ SNaPshot } & $\mathrm{C}$ & $X T A G C$ CACTT & 1 & - \\
\hline & & & & $\mathrm{T}$ & $X T A G C$ TACTT & 9 & - \\
\hline \multirow{2}{*}{5} & \multirow{2}{*}{ CS HinfI4 } & \multirow{2}{*}{ SNP } & \multirow{2}{*}{ SNaPshot } & $\mathrm{C}$ & XАATACACTC & 1 & - \\
\hline & & & & G & XAATAGACTC & 9 & - \\
\hline \multirow{2}{*}{6} & \multirow{2}{*}{ CD AscIA } & \multirow{2}{*}{ SNP } & \multirow{2}{*}{ CAPS } & - & $X$ TAATTT & 1 & 908 \\
\hline & & & & - & $X$ AAATTT & 9 & $731+171$ \\
\hline \multirow{2}{*}{7} & $\mathrm{CD} A \mathrm{scIR}$ & SNP & $C A P S$ & - & $X G A A \mathbf{A T T N}$ & 1 & 908 \\
\hline & CD ASCIB & $\mathrm{SNP}$ & $C A P S$ & - & $X G A A \mathbf{T T T}$ & 9 & $613+295$ \\
\hline 8 & CD AscI4 & SNP & CAPS & - & $X G A A \mathbf{A T T}$ & 1 & 497 \\
\hline 0 & CD Asc14 & SNP & CAPS & - & $X G A A \mathbf{T T T}$ & 9 & $351+146$ \\
\hline 0 & K1K2Hinft6R & & & $\mathrm{T}$ & TTTTAT & 1 & - \\
\hline 9 & КIК2Hinfl6B & SNP & SNaPshot & G & TTTGAT & 9 & - \\
\hline 10 & $\mathrm{~K} 1 \mathrm{~K} 2 \mathrm{Hinfl5A}$ & INDEI & SNaPshot & $\mathrm{T}$ & ATATCT TATTCTTATTG & 1 & - \\
\hline 10 & KIK L HINIISA & INDEL & SNaPsnot & A & A------- TATTCTTATTC & 2 & - \\
\hline 11 & K1K2 Tru9IR & JNDFI & & - & XAAATAACTTTTTTGT & 1 & 227 \\
\hline 11 & KIK2 IrU9IB & INDEL & polymorphism & - & XAAA ------- TTTTTGT & 2 & 222 \\
\hline & & & length & - & XGGATTTTTTTTTTAGAAAT & 1 & 81 \\
\hline 12 & CD Hinfl8A & INDEL & polymorphism & - & 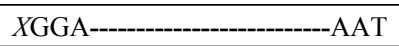 & 2 & 69 \\
\hline
\end{tabular}




\section{Table 3(on next page)}

Description of cpDNA chlorotypes identified in investigated populations of A.halleri.

Characters used in coding correspond to coding column in Table 2. Correspondence to the mutations observed by Pauwels et al. (2005) in RFLP study was given. Mutation numbers corresponds with Figure 1. 


\begin{tabular}{|c|c|c|c|c|c|c|c|c|c|c|c|c|c|}
\hline \multicolumn{2}{|c|}{$\begin{array}{l}\text { Mutation } \\
\text { number }\end{array}$} & 1 & 2 & 3 & 4 & 5 & 6 & 7 & 8 & 9 & 10 & 11 & 12 \\
\hline \multicolumn{2}{|c|}{$\begin{array}{l}\text { Mutation } \\
\text { name } \\
\text { (cf. Pauwels } \\
\text { et al. 2005) }\end{array}$} & 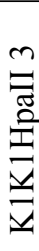 & 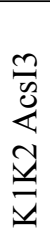 & $\begin{array}{l}\stackrel{\Omega}{\sigma} \\
\stackrel{\Xi}{\Xi} \\
\vec{\nabla} \\
\vec{\nabla}\end{array}$ & $\begin{array}{l}\exists \\
\Xi \\
\text { Un } \\
\text { U }\end{array}$ & 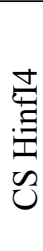 & 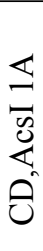 & $\begin{array}{l}\frac{n}{v} \\
0 \\
0 \\
0 \\
0\end{array}$ & $\begin{array}{l}\frac{\pi}{0} \\
0 \\
0 \\
0\end{array}$ & 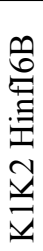 & 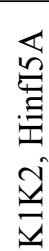 & 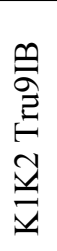 & 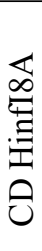 \\
\hline \multirow{12}{*}{ 总 } & $\mathrm{A}$ & 9 & 9 & 9 & 1 & 1 & 1 & 1 & 9 & 1 & 1 & 1 & 1 \\
\hline & B & 9 & 9 & 9 & 9 & 1 & 1 & 1 & 9 & 1 & 1 & 1 & 1 \\
\hline & $\mathrm{C}$ & 9 & 9 & 9 & 1 & 1 & 1 & 9 & 9 & 1 & 1 & 1 & 1 \\
\hline & $\mathrm{D}$ & 9 & 1 & 9 & 1 & 1 & 1 & 1 & 9 & 1 & 1 & 1 & 1 \\
\hline & $\mathrm{E}$ & 1 & 9 & 9 & 1 & 1 & 1 & 1 & 9 & 1 & 1 & 1 & 1 \\
\hline & $\mathrm{P}$ & 1 & 9 & 9 & 1 & 1 & 1 & 1 & 9 & 1 & 2 & 1 & 1 \\
\hline & $\mathrm{F}$ & 1 & 9 & 9 & 1 & 1 & 1 & 1 & 9 & 1 & 1 & 2 & 1 \\
\hline & $\mathrm{G}$ & 1 & 9 & 9 & 1 & 1 & 1 & 1 & 1 & 1 & 2 & 1 & 1 \\
\hline & $\mathrm{H}$ & 1 & 9 & 1 & 1 & 9 & 1 & 1 & 1 & 1 & 2 & 1 & 1 \\
\hline & I & 1 & 9 & 9 & 1 & 1 & 1 & 1 & 1 & 9 & 2 & 1 & 1 \\
\hline & $\mathrm{J}$ & 1 & 9 & 9 & 1 & 1 & 9 & 1 & 1 & 1 & 2 & 1 & 2 \\
\hline & $\mathrm{M}$ & 1 & 9 & 9 & 1 & 1 & 1 & 1 & 1 & 1 & 2 & 1 & 2 \\
\hline
\end{tabular}




\section{Table 4 (on next page)}

Chlorotype distribution among investigated populations of $A$.halleri and molecular diversity indices 
1
2
3

\begin{tabular}{|c|c|c|c|c|c|c|c|c|c|c|c|c|c|c|c|c|c|c|}
\hline & \multicolumn{17}{|c|}{ Chlorotype } & \\
\hline Pop & $n_{i}$ & $\mathrm{~A}$ & $\mathrm{~B}$ & $\mathrm{C}$ & $\mathrm{D}$ & $\mathrm{E} \alpha$ & $\mathrm{E}$ & $\mathrm{F}$ & $\mathrm{G}$ & $\mathrm{H}$ & I & $\mathrm{J}$ & $\mathrm{K}$ & $\mathrm{L}$ & $\mathrm{M}$ & $\mathrm{O}$ & $\mathrm{a}_{7}$ & $H_{\mathrm{Sd}}$ \\
\hline A05 & 14 & & & & & & 14 & . & . & & . & & . & & . & & 1.000 & 0.000 \\
\hline A08 & 45 & & & & & & 45 & . & . & & . & . & . & . & . & . & 1.000 & 0.000 \\
\hline A09 & 20 & & & & & & 20 & . & . & & . & . & . & . & . & . & 1.000 & \begin{tabular}{|l|}
0.000 \\
\end{tabular} \\
\hline CZ04 & 14 & & 13 & & & & . & 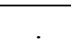 & . & & 1 & 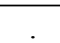 & . & . & . & . & 1.759 & 0.143 \\
\hline CZ05 & 24 & 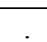 & 22 & . & . & . & . & 2 & . & . & . & . & . & . & . & . & 1.762 & 0.159 \\
\hline CZ06 & 12 & & 12 & & & & & - & . & & 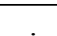 & & . & - & . & - & 1.000 & 0.000 \\
\hline CZ14 & 20 & & & & & & & & 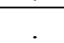 & & & 20 & 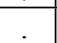 & . & . & 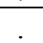 & 1.000 & 0.000 \\
\hline CZ16 & 57 & & & & & & 56 & . & . & & . & 1 & . & & . & . & 1.231 & 0.035 \\
\hline CZ18 & 9 & & & . & & & 9 & . & . & & & & . & . & . & . & 1.000 & 0.000 \\
\hline CZ20 & 33 & . & & . & & . & . & . & . & & 11 & 22 & . & 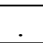 & . & . & 1.999 & 0.458 \\
\hline CZ21 & 30 & 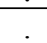 & & & & & . & . & 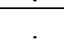 & & 24 & 6 & . & . & . & 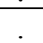 & 1.972 & 0.331 \\
\hline CZ22 & 32 & 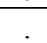 & . & & & 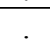 & & . & . & & . & 32 & . & . & . & . & 1.000 & 0.000 \\
\hline D01 & 7 & & & 2 & & & 4 & 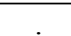 & 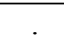 & & & 1 & . & . & . & . & 3.000 & 0.667 \\
\hline D02 & 8 & 2 & & 2 & & & 1 & . & . & 1 & . & 2 & . & . & . & . & 4.983 & 0.893 \\
\hline D03 & 9 & 2 & . & $\dot{0}$ & . & . & 6 & . & . & 1 & . & . & . & . & . & . & 2.960 & 0.556 \\
\hline D04 & 11 & 5 & & & & & 2 & & . & 4 & & & . & . & . & 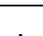 & 2.990 & 0.691 \\
\hline D08 & 12 & 1 & . & . & 10 & . & 1 & $\dot{x}$ & . & . & . & . & . & . & . &. & 2.674 & 0.318 \\
\hline D09 & 18 & 3 & . & . & 15 & & & . & . & & . & . & . & 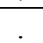 & . & . & 1.962 & 0.294 \\
\hline D11 & 18 & 5 & & . & \begin{tabular}{|l|}
9 \\
\end{tabular} & . & 4 & . & . & . & . & . & . & 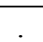 & . & 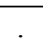 & 2.987 & \begin{tabular}{|l|l}
0.660 \\
\end{tabular} \\
\hline D12 & 18 & 4 & & & 6 & & 8 & . & . & &. & . & . & . & . &. & 2.989 & \begin{tabular}{|l|l}
0.680 \\
\end{tabular} \\
\hline D13 & 20 & & . & . & \begin{tabular}{|l|}
17 \\
\end{tabular} & . & 3 & . & . & . & . & . & . & $\cdot$ & . & . & 1.940 & \begin{tabular}{|l|l}
0.268 \\
\end{tabular} \\
\hline D14 & 11 & 1 & . & . & 10 & . & . & & . & 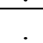 & . & 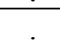 & . & 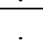 & . & 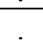 & 1.879 & 0.182 \\
\hline PL02 & 21 & & 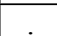 & & & & & 14 & . & &. & 7 & . & . & . & . & 1.999 & 0.467 \\
\hline PL03 & 15 & . & . & . & . & . & 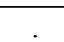 & 13 & . & & . & 2 & . & . & . & . & 1.934 & \begin{tabular}{|l|l}
0.248 \\
\end{tabular} \\
\hline PL07 & 19 & -7 & . & . & . & . & 4 & 15 & . & . &. & . & . & 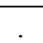 & . & 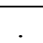 & 1.985 & \begin{tabular}{|l|l}
0.351 \\
\end{tabular} \\
\hline PL08 & 12 & . & . & . & . & . & & 5 & . & . & & 7 & . & . & . &. & 2.000 & \begin{tabular}{|l|}
0.530 \\
\end{tabular} \\
\hline PL32 & 27 &. & . & . & . & . & 11 & 9 & . & & 7 & . & . & . & . & . & 2.992 & \begin{tabular}{|l|l}
0.681 \\
\end{tabular} \\
\hline PL33 & 21 & . & . & & & & . & 7 & . & & 14 & & . & . & . & . & 1.999 & \begin{tabular}{|l|l}
0.467 \\
\end{tabular} \\
\hline PL37 & 40 & . & . & . & & 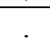 & 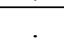 & . & . & & . & 40 & . & . & . & . & 1.000 & \begin{tabular}{|l|l}
0.000 \\
\end{tabular} \\
\hline PL38 & 29 & . & . & . & & & & 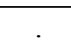 & - & & 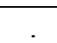 & 29 & 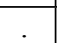 & & . & 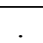 & 1.000 & \begin{tabular}{|l|l}
0.000 \\
\end{tabular} \\
\hline PL39 & 39 & & & & & & & & & & & 39 & . & & . & . & 1.000 & \begin{tabular}{|l|l}
0.000 \\
\end{tabular} \\
\hline PL40 & 39 & . & . & . & . & . & . & . & . & . & . & 39 & . & . & . & $\cdot$ & 1.000 & \begin{tabular}{|l|l}
0.000 \\
\end{tabular} \\
\hline PL41 & 39 & & 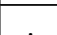 & . & & & . & . & . & & 1 & 38 & . & . & . & - & 1.329 & 0.051 \\
\hline PL42 & 39 & & & & & & & & 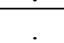 & & 28 & 11 & . & & . & . & 1.994 & 0.416 \\
\hline PL43 & 39 & & & & & & & . & . & & . & 39 & 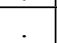 & & . & & 1.000 & 0.000 \\
\hline PL44 & 41 & 14 & & 27 & . & . & & & . & 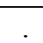 &. & 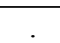 & . & . & . & . & 1.999 & \begin{tabular}{|l|l}
0.461 \\
\end{tabular} \\
\hline PL45 & 39 & & . & & & & 2 & 36 & & . & . & 1 & . & . & . & . & 1.883 & \begin{tabular}{|l|l}
0.148 \\
\end{tabular} \\
\hline PL46 & 23 & & & & & & & & 23 & & 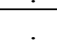 & . & . & & . & & 1.000 & \begin{tabular}{|l|l}
0.000 \\
\end{tabular} \\
\hline PL47 & 24 & . & . & . & . & 4 & . & . & 20 & . & . & . & . & . & . & . & 1.952 & \begin{tabular}{|c|}
0.290 \\
\end{tabular} \\
\hline PL48 & 20 & & & & & & & & 20 & & & & & & & & 1.000 & \begin{tabular}{|l|l}
0.000 \\
\end{tabular} \\
\hline PL49 & 22 & & & & & 2 & & & 20 & & & & . & & . & . & 1.798 & \begin{tabular}{|l|l|}
0.173 \\
\end{tabular} \\
\hline PL50 & 34 & & & 34 & & & & & . & & . & $\cdot$ & . & & . & & 1.000 & 0.000 \\
\hline SK02 & 22 & & 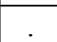 & & & & 4 & 18 & & & & & 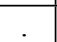 & & . & & 1.967 & \begin{tabular}{|l|l}
0.312 \\
\end{tabular} \\
\hline SK05 & 46 & & . & & & & & 19 & 1 & & 25 & 1 & & & . & . & 2.565 & \begin{tabular}{|l|}
0.545 \\
\end{tabular} \\
\hline SK10 & 21 & & & & & 7 & 2 & 11 & . & & . & 1 & - & & . & & 3.377 & \begin{tabular}{|l}
0.633 \\
\end{tabular} \\
\hline SK12 & 16 & & & & & 7 & 2 & 7 & & & . & $\cdot$ & . & & . & . & 2.915 & \begin{tabular}{|l|}
0.642 \\
\end{tabular} \\
\hline UA01 & 31 & & & & & 21 & & . & 10 & & & 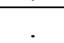 & 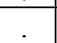 & & . & 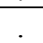 & 1.998 & 0.452 \\
\hline UA02 & 32 & & & & & 30 & & . & 2 & & & & $\dot{.}$ & & $\dot{.}$ & & 1.638 & \begin{tabular}{|l|l}
0.121 \\
\end{tabular} \\
\hline UA04 & 32 & . & . & . & . & 5 & . & . & 27 & & . & . & $\dot{.}$ & . & & . & 1.932 & \begin{tabular}{|l|l}
0.272 \\
\end{tabular} \\
\hline UA05 & 32 & & & & & 6 & & . & 14 & & & & - & & 12 & & 2.962 & 0.653 \\
\hline UA06 & 16 & & & & & 1 & & & 12 & & & & 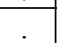 & & 3 & & 2.671 & 0.425 \\
\hline UA07 & $\varepsilon$ & & & & & & & & 6 & & & & & & 2 & & 2.000 & 0.429 \\
\hline Total & 1280 & \begin{tabular}{|l|}
37 \\
\end{tabular} & \begin{tabular}{|l|}
47 \\
\end{tabular} & 65 & 67 & 83 & 198 & 156 & 155 & 6 & 111 & 338 & 0 & 0 & 17 & 0 & 6.927 & - \\
\hline
\end{tabular}




\section{Table 5 (on next page)}

Comparison of within-population diversity indices among different geographical regions

$n$ - number of populations in a region, $A_{s c}$ - chlorotypic richnes, $H_{s d}$ - chlorotype diversity index 
1

2

3

4

5

6

7

8

9

10

11

\begin{tabular}{|l|c|c|c|}
\hline geographical group & $\mathrm{n}$ & $\mathrm{A}_{\mathrm{Sc}}$ & $\mathrm{H}_{\mathrm{Sd}}$ \\
\hline Western Carpathians & 5 & 2.636 & 0.547 \\
\hline Eastern Carpathians & 11 & 1.895 & 0.285 \\
\hline Sudetes & 12 & 1.358 & 0.143 \\
\hline Harz & 6 & 2.405 & 0.420 \\
\hline Alps & 3 & 1.000 & 0.000 \\
\hline Bohemian Forest & 10 & 2.169 & 0.181 \\
\hline N Carpathian Foreland & 5 & 1.960 & 0.303 \\
\hline
\end{tabular}




\section{Table 6(on next page)}

Results of AMOVA analysis

All results were significant with $\alpha=0.05$. Significance test were carried out using permutaion test (10100 permutations). 
4

5

6

7

8

9

10

11

12

13

14

15

16

17

18

19

\begin{tabular}{|l|l|r|r|r|r|}
\hline & Source of variation & d.f. & $\begin{array}{c}\text { Sum } \\
\text { of squares }\end{array}$ & $\begin{array}{c}\text { Variance } \\
\text { components }\end{array}$ & $\begin{array}{c}\text { Precentage } \\
\text { of variation }\end{array}$ \\
\hline All populations & Among populations & 51 & 1329.890 & 1.09838 & 79.16 \\
\hline & Within populations & 1233 & 356.479 & 0.28912 & 20.84 \\
\hline Western Carpathians & Among populations & 5 & 33.292 & 0.23835 & 23.95 \\
\hline & Within populations & 147 & 111.244 & 0.75676 & 76.05 \\
\hline Eastern Carpathians & Among populations & 9 & 32.980 & 0.14726 & 46.44 \\
\hline & Within populations & 230 & 39.066 & 0.16985 & 53.56 \\
\hline Sudetes & Among populations & 11 & 408.052 & 1.01023 & 85.66 \\
\hline & Within populations & 427 & 72.235 & 0.16917 & 14.34 \\
\hline Harz & Among populations & 5 & 6.934 & 0.06793 & 18.55 \\
\hline & Within populations & 91 & 27.148 & 0.29833 & 81.45 \\
\hline Alps & Among populations & 2 & 0.000 & 0.00000 & 0.00 \\
\hline & Within populations & 76 & 0.000 & 0.00000 & 0.00 \\
\hline Bohemian Forest & Among populations & 9 & 133.130 & 0.91778 & 74.57 \\
\hline & Within populations & 161 & 50.379 & 0.31291 & 25.43 \\
\hline N Carpathian Foreland & Among populations & 4 & 18.696 & 0.20423 & 26.78 \\
\hline & Within populations & 101 & 56.408 & 0.55849 & 73.22 \\
\hline k-means clustering (6) & Among groups & 5 & 1102.418 & 1.03618 & 65.82 \\
\hline & Among populations & 46 & 290.472 & 0.24899 & 15.82 \\
\hline & Within populations & 1233 & 356.479 & 0.28912 & 18.36 \\
\hline Geographic location (7) & Among groups & 6 & 759.806 & 0.64481 & 42.88 \\
\hline & Among populations & 45 & 633.085 & 0.56992 & 37.90 \\
\hline & Within populations & 1233 & 356.749 & 0.28912 & 19.23 \\
\hline
\end{tabular}

22 
1

Minimum spanning tree (MST) presenting relationships between cpDNA haplotypes in $A$. halleri.

Coloured circles represent haplotypes, white circle represent missing haplotype. Numbers indicate mutations as given in Table 2 .

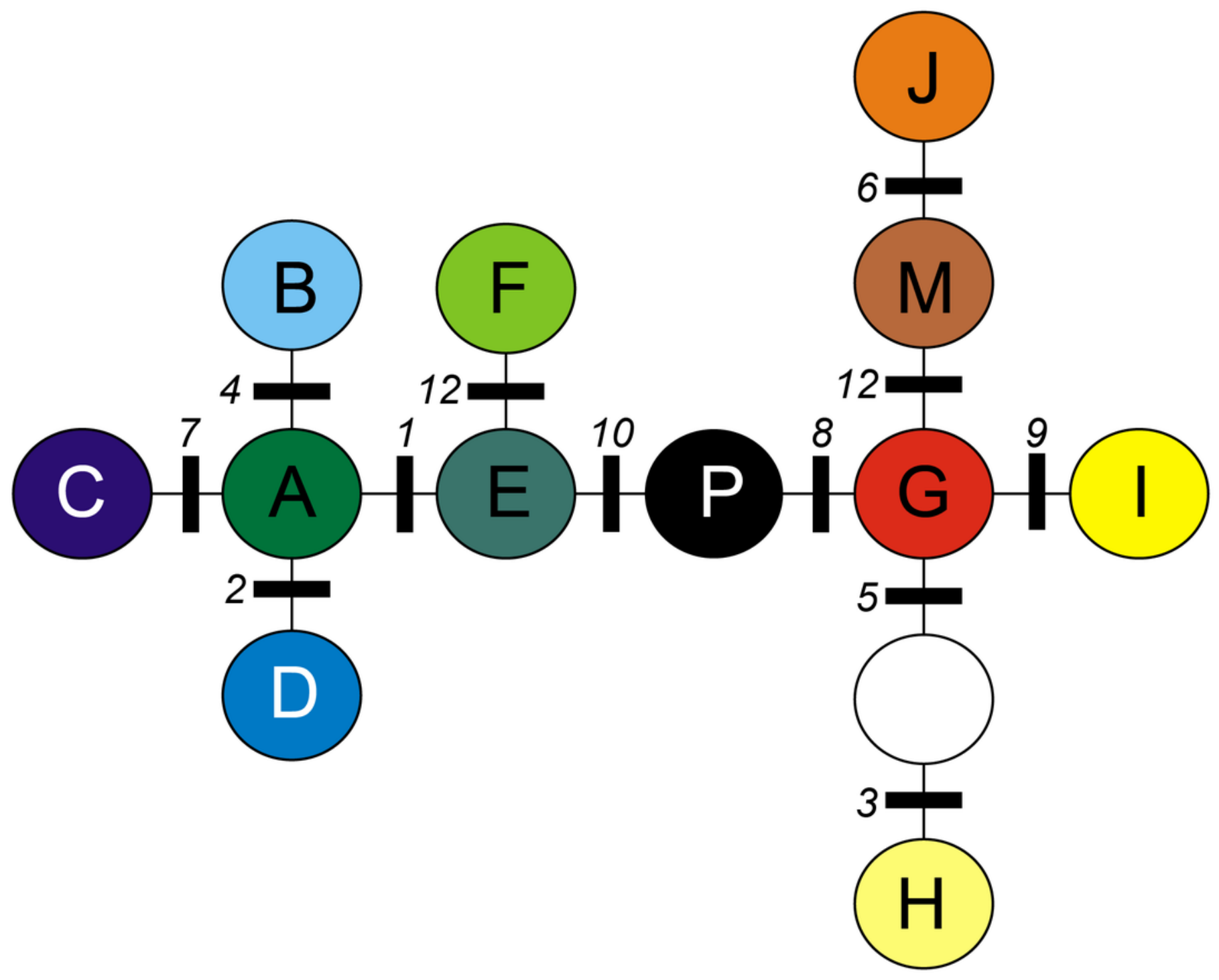


2

Geographic distribution of cpDNA haplotypes present in the investigated populations of A. halleri.

Bar charts represent the frequency of each haplotype in each investigated population.

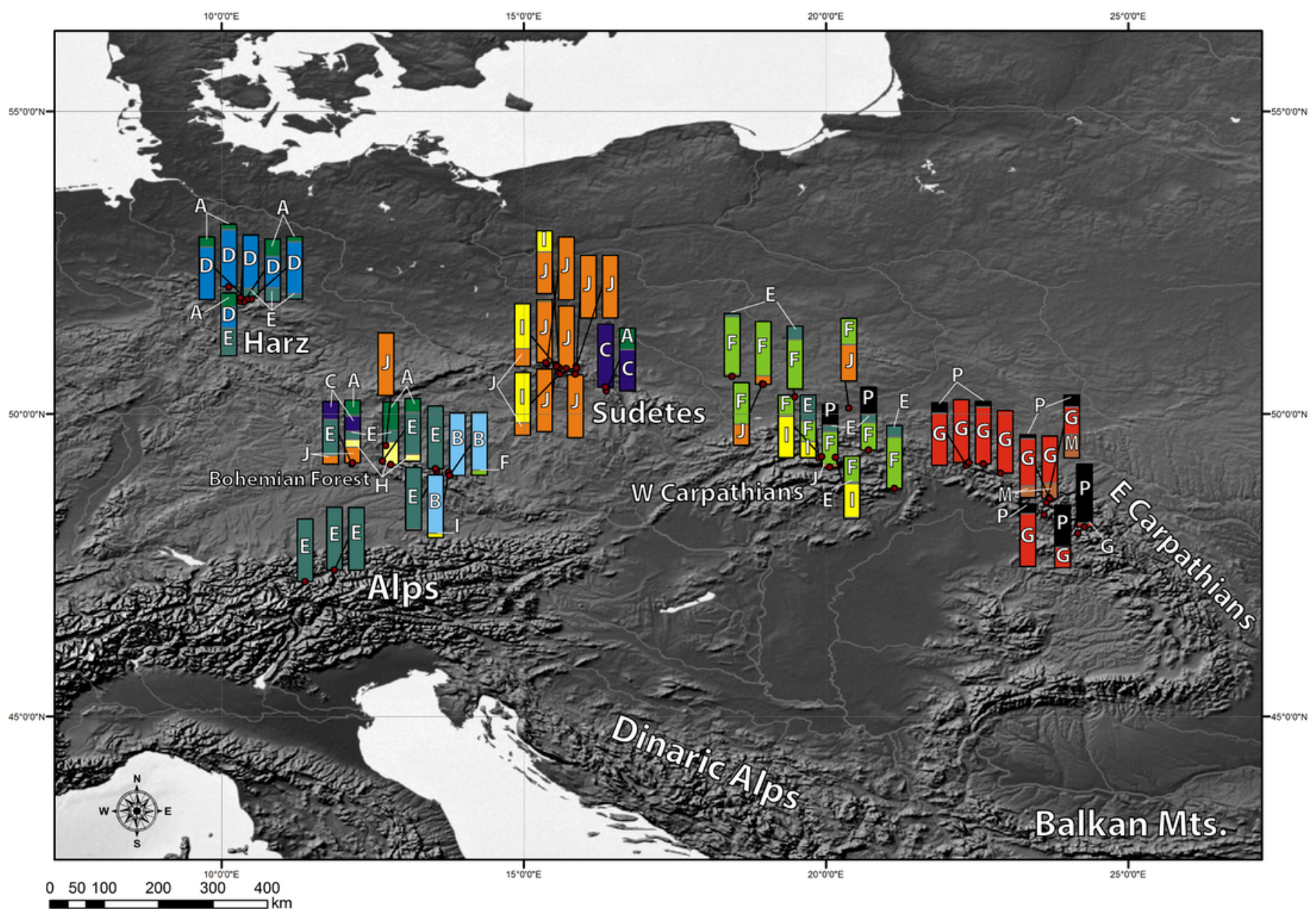




\section{3}

Geographic distribution of within-population cpDNA allelic richness $\left(A_{s c}\right)$ in the populations investigated.

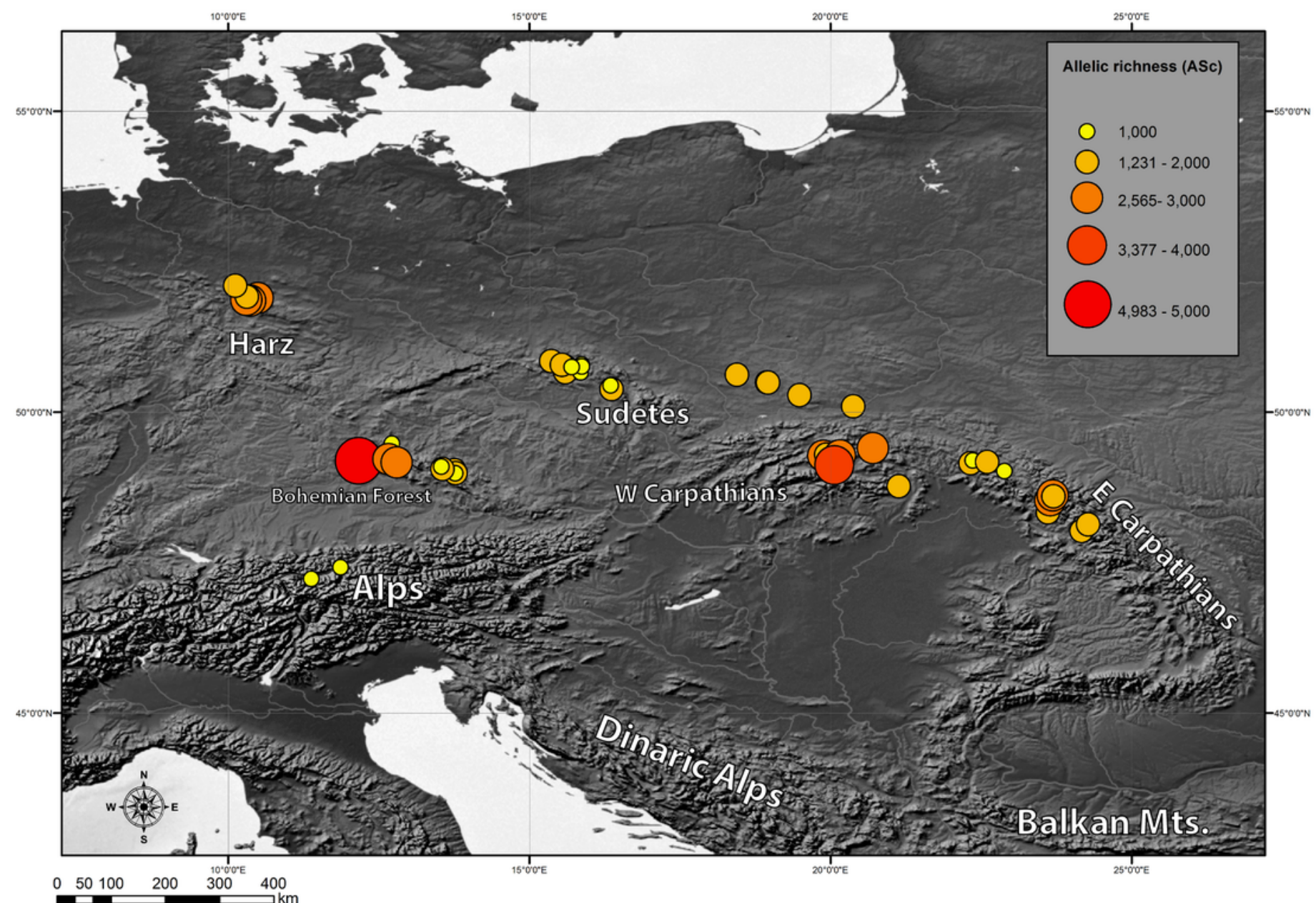


4

Results of spherical k-means clustering (SKMC).

SKMC of investigated populations carried out using Shperikm (Hill et al., 2013). Statistically optimal level of $k=6$ was presented (see Supplemental Information 5 for other levels of $k$ ).

Different colours (and numbers from 1 to 6 ) correspond to different clusters identified by SKMC. Population differentiation was inferred from a data matrix of chlorotype frequencies.

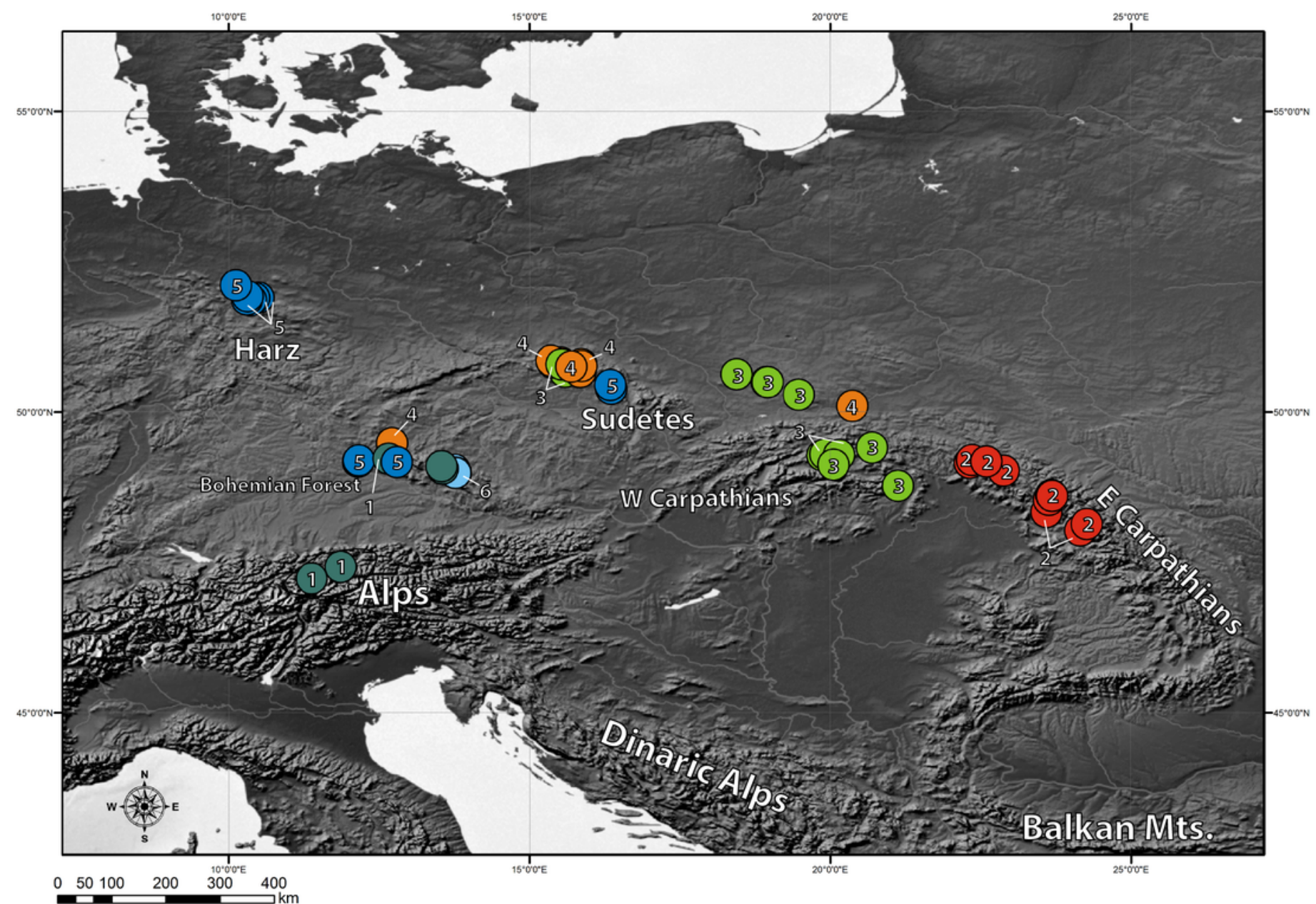




\section{5}

\section{Results of SKMC and AMOVA}

(A) Value of the quasi-Akaike information criterion as a function of $k$ (number of groups identified by SKMC analysis). Statistically optimal solution (having the lowest value of the quasi-Akaike criterion) is marked with a red line. (B) Percent of genetic variance among groups of populations identified by SKMC (blue), among populations within groups (green) and within populations (black) calculated by AMOVA. Statistically optimal solution of SKMC is marked with a red line. 
A

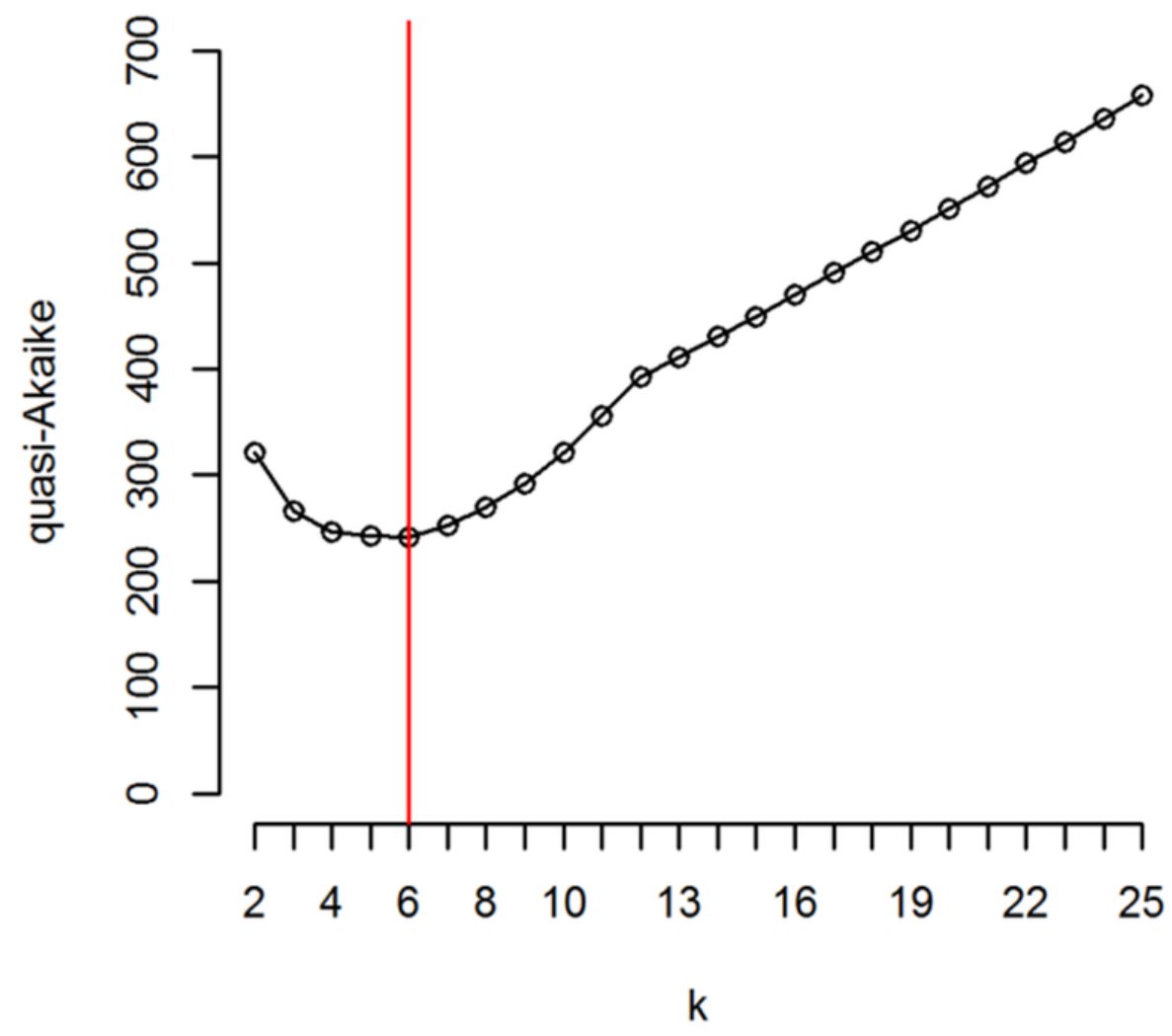

B

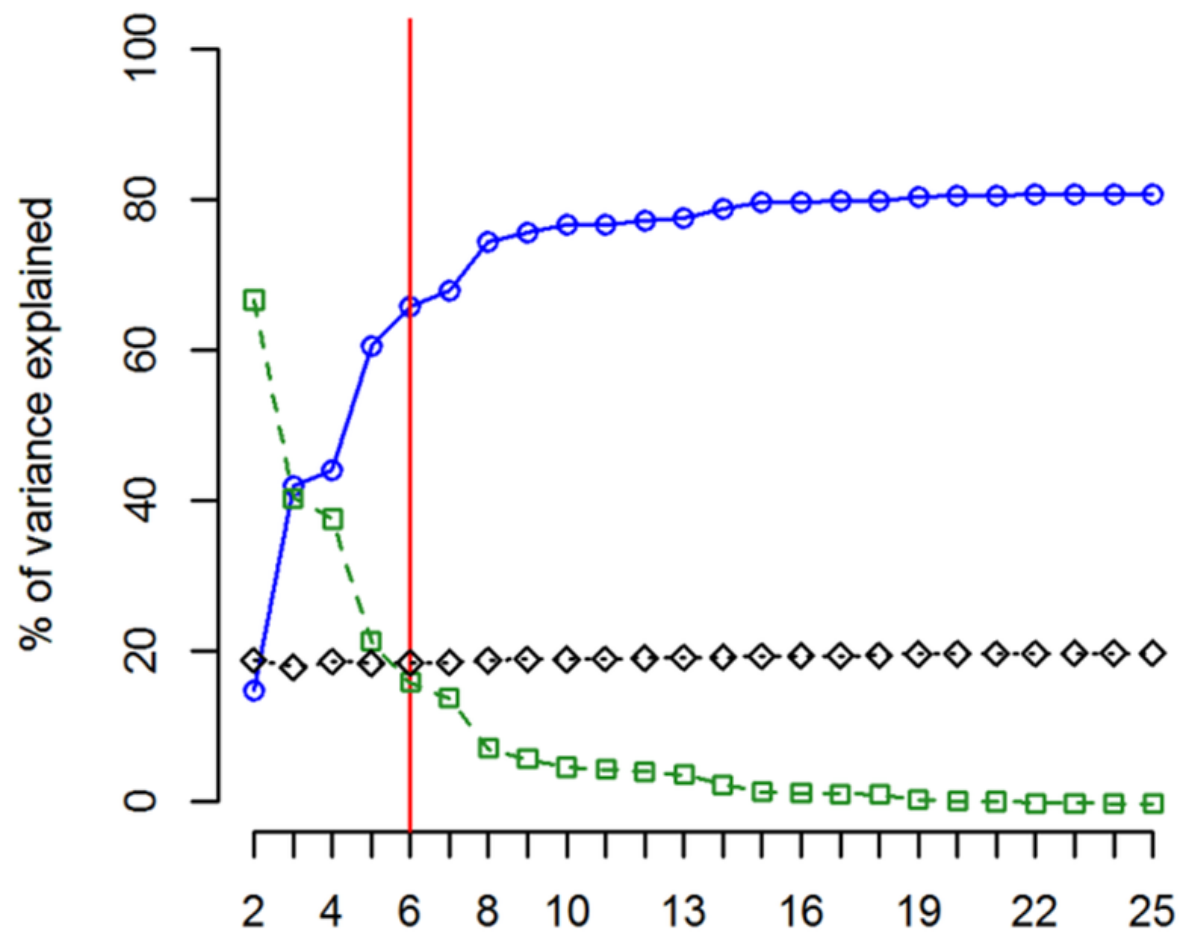


6

Results of modelling experiments.

Binary maps of distributions based on the results of ensemble models (mean of probabilities) are shown. Results are based on the data from three different paleoclimate models: CCSM4, MIROC and MPI ESM, as well as current climate observations. Species range was reconstructed for two time periods: Last Glacial Maximum (LGM, ca. 21 kyr BP) and MidHolocene (ca. 6 kyr BP).

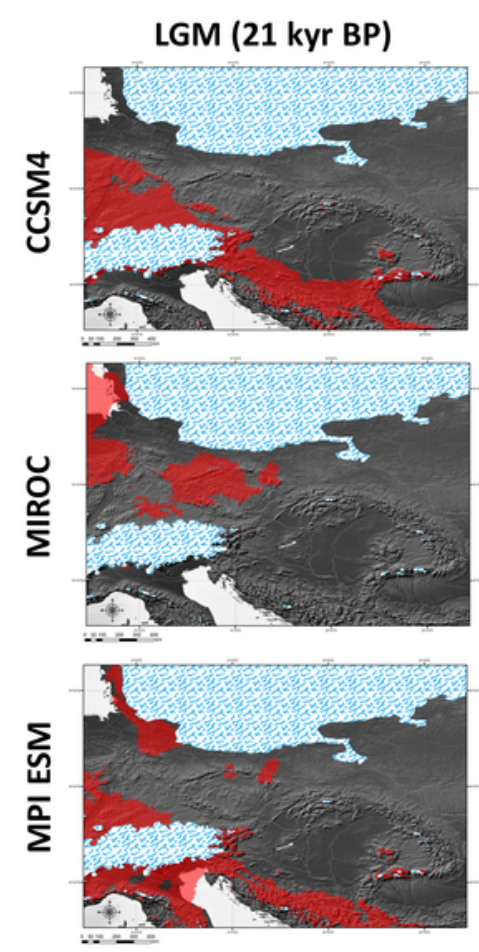

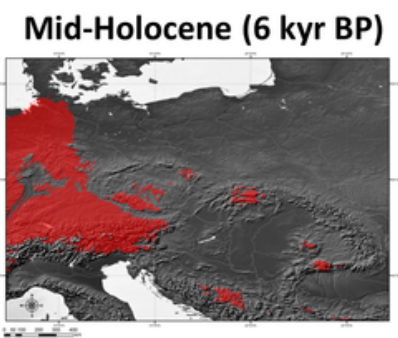
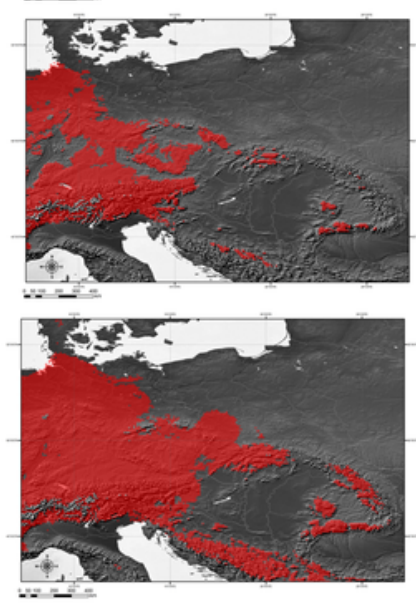

Current climate

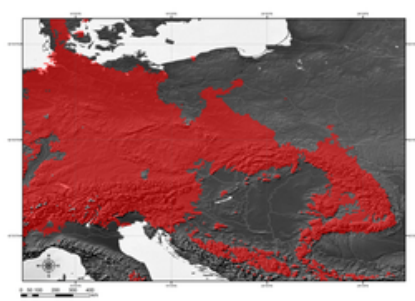

